\title{
Influence of Partner Relationship and IT Integration on Supply Chain Capabilities: An Empirical Relational Paradigm
}

\author{
Santanu Mandal \\ Faculty of Operations \& IT \\ IBS, Hyderabad, IFHE University \\ India \\ shaan.nitw@gmail.com
}

\begin{abstract}
Supply chain relationships are now becoming more important due to efficient and effective information sharing and leading to integration. The purpose of this study is to investigate the influence of trust and commitment on integrated logistics capabilities. A second purpose is to explore the influence of integrated logistics capabilities on supply chain agility, resilience and robustness. The study employed a cross-sectional web-based survey of 183 logistics and supply chain professionals from Indian Manufacturing firms for data collection. Confirmatory factor analysis was employed for testing the reliability and validity of the measurement instrument. Further, partial least squares was utilized for testing the proposed relationships. The study found positive effects of trust and commitment on integrated logistics capabilities which in turn positively affect the development of supply chain capabilities viz. agility, resilience and robustness. Further, trust was found to have a positive effect on commitment. The study is the first to empirically validate the relationship between integrated logistics capabilities and three dominant supply chain capabilities viz. agility, resilience and robustness. Secondly, it also addressed the impact of two dominant relational attributes that have not been explored. The study empirically explored that logistics is an integral part of supply chain management as suggested in its definition. Further, our study undersigned IT integration as a significant moderator in the enabler-mechanism-outcome paradigm.
\end{abstract}

Keywords: trust, commitment, agility, resilience, robustness, IT integration 


\section{Introduction}

Recent competition has shifted from firms to supply chains (Christopher, 2000). Firms are contemplating to invest resources for developing their supply chain (SC) operations and safeguard them in the face of growing disruptions (Wagner \& Bode, 2008). Further, firms are focusing on developing their logistics capabilities as well. Studies have underscored that integration of logistics capabilities lead to supply chain capabilities. The current investigation adopts the definition of logistics management given by Council of Logistics Management (2003):

"Logistics management is that part of Supply Chain Management that plans, implements, and controls the efficient, effective forward and reverse flow and storage of goods, services, and related information between the point of origin and the point of consumption in order to meet customer requirement."

Accordingly, the current study considers logistics management as an integral part of supply chain management. Further, the study posits that integration of logistics capabilities of a firm are necessary at its supply chain level for developing supply chain capabilities (Gligor \& Holcomb, 2012; Gligor \& Holcomb, 2014). The role of logistics capabilities is all the more important when time and quality based competition is intense.

It is the logistics capabilities that contributed to the success of many firms operating in commodity or convenience goods markets (Christopher 1994; Mentzer and Williams 2001). Thus, logistics capabilities enhance a firm's competitiveness through enhancing both economic (cost leadership/efficiency) and market-based (differentiation/ effectiveness) values (Mentzer, Min, and Bobbitt 2004; Wen, 2012).

Firms have to develop certain supply chain capabilities to adapt to their dynamic environments, respond to customer needs and adjust proactively to supply chain disruptions. We consider three such capabilities in this study: supply chain (SC) agility, supply chain (SC) resilience and supply chain (SC) robustness.SC agility is defined as the ability of a supply chain to respond to market demands in a speedy manner (Swafford et al., 2008).SC resilience is the ability of supply chain to restore operations to normal operating state, within sufficient time after a disruption (Christopher \& Peck, 2004; Brandon-Jones et al., 2014). SC robustness is the ability of supply chain to sustain its operation despite internal and external disruptions (BrandonJones et al., 2014).

Logistics capabilities when suitably integrated for developing supply chain capabilities can lead to competitive advantage (Gligor \& Holcomb, 2012). Therefore, logistics capabilities of the focal firm must be synchronized with that of other supply chain partners. This notion finds support in the most accepted premise that business process integration is essential for efficient supply chain management (Esper and Defee, 2010). The current study considers integration of logistics capabilities as ardent for developing dynamic capabilities of SC agility, SC resilience and SC robustness. Further, our study considers the influence of relational attributes of trust and commitment on integration of logistics capabilities. Further, how these linkages vary with the presence of IT integration is also explored. This is because IT integration aids in effective and efficient information sharing that is vital for enhancing and sustaining collaborative efforts and joint decision making. Also the study explored the inter-relationship among trust, commitment, integrated logistics capabilities with agility, resilience and robustness. The study adopted "enabler - mechanism outcome (performance)" paradigm and posited trust and commitment as enablers of the integrated logistics capabilities i.e. the mechanism that results in performance outcomes of agility, resilience and robustness. 
This investigation basically addresses the following research questions:

(1) What are the influences of trust and commitment on integrated logistics capabilities?

(2) What are the influences of integrated logistics capabilities on SC agility, SC resilience and SC robustness?

(3) What is the contribution of IT integration on trust and commitment with integrated logistics capabilities?

(4) Do integrated logistics capabilities mediate the impact of trust and commitment on agility, resilience and robustness?

\section{Theoretical Background}

\section{The Relational View of Firm}

Barney (1991) argued that firms differ in their performance due to heterogeneity in resource ownerships. This explained that firms that possess different capabilities as resources when combined and deployed give rise to capabilities. Resources are something that is of strength or weakness for a firm, while capabilities impart the firm with competitive advantage when developed uniquely (Amit \& Schoemaker, 1993; Wernerfelt, 1984).

The resource based view was subsequently extended by Dyer \& Singh (1998) through their relational view. This suggested that the sources of competitive advantage do not necessarily reside within a firm; rather they are embedded in its relational networks. Dyer \& Singh (1998) suggested four sources of inter-firm competitive advantage: (1) relation- specific assets, (2) knowledgesharing routines, (3) complementary resource/capabilities, and (4) effective governance. Trust and commitment meet the criteria of "relation-specific assets" and criteria for "effective governance".

Supply chain partners will make every effort to form closer relationships to reduce costs and increase profits. Hence maintenance of cooperative relationships is an important issue for them. Since Morgan \& Hunt (1991) proposed the commitment-trust model, many researchers have probed into various trust and commitment related issues. Supply chain sectors are now one of the most competitive industries at present. They are now characterized by intense competition, dynamic needs leading to innovative products, knowledge exchange, global operations etc. Supply chains are inter-connected network of firms engaged in exchange relationships; hence the importance of relational attributes is paramount when it comes to the development of capabilities along the chain. Also a finished product is produced with several components procured from different partners in the chain. Therefore, trust and commitment of partners is extremely important.

The commitment-trust theory has been investigated in different contexts (Friman et al., 2002; Lancastre \& Lages, 2006; Goo \& Nam, 2007) and the variables in the commitment trust model has been adopted in various forms for allied works on buyersupplier relationships (Mohr \& Spekman, 1994; Zaheer et al., 1998;Naude \& Buttle, 2000;Wu \& Cavusgil, 2006; Rauyruen \& Miller, 2007; Gaur et al., 2011), partnership quality (Lambert et al., 2004; Kedia \& Lahiri, 2007; Lahiri \& Kedia, 2009; Srinivasan et al., 2011; Lahiri et al., 2012) and supply chain relationships (Wathne \& Heide, 2004; Kwon \& Suh, 2006; Fynes et al., 2004; 2005a; 2005b;2008; Su et al.,2008).

The commitment-trust theory argues that there is absence of an explicit "buyer-seller" relationship in network alliances and they are more like partners to an exchange. Also it argues that such alliance success is largely dependent on relational attributes (e.g. trust, commitment, communication, cooperation etc.) leading to efficient relationships. Research on trustcommitment theory suggests overall satisfaction as a key ingredient along with trust and commitment (Garbarino \& Johnson, 1999; Ruben et al., 2015). This overall satisfaction is a cumulative construct 
as it encompasses all satisfaction forms commencing with those related to products and service usage to experience with physical facilities (Bowden et al., 2015). However, supply chain relationships have undersigned trust and commitment as the focal factors in exploring the different facets of supply chain relationship quality (Kwon \& Suh, 2005, 2006; Fynes et al., 2005a, 2005b) including buyer partnership quality (Srinivasan et al.,2011). As the current study focuses on the influence of relationship quality on the integration i.e. unification of firm level logistics capabilities for developing supply chain capabilities (e.g. resilience, robustness and agility); we have not incorporated "satisfaction". As the study is not dealing with customer experiences and post purchase behaviour; the inclusion of "satisfaction" is not deemed necessary.

Trust and commitment form the basis of supply chain relationships (Kwon \& Suh, 2005). Further the presence of trust and commitment among supply chain partners enhance the speed at which the supply chain can respond to a market need or disruption. As a result, they qualify as "relation-specific" assets in the context of development of SC agility, resilience and robustness. Further, trust and commitment enforces governance in supply chain through fostering transparency and delegation of responsibilities (Kwon \& Suh, 2005). In the context of relational view, it is the contention of this research that they are essential ingredients for developing integrated logistics capabilities across members of the supply chain. Further, such integrated logistics capabilities will result in the development of higher order supply chain capabilities like SC agility, SC resilience and SC robustness that are dynamic in nature (Teece et al., 1997). The next segment strengthens the above argument.

\section{Defining Logistics Capabilities}

Logistics capabilities have been widely researched since a decade and have been gaining momentum in response to a firm's efforts in constantly devising supply chain capabilities for meeting contingencies (Gligor \& Holcomb, 2014). Logistics capabilities refer to those skills attributes knowledge and processes in an organization that enables it to achieve extraordinary performance and manage its operations efficiently and effectively (Morash et al., 1996; Mentzer et al., 2004; Gligor \& Holcomb, 2012).

The Global Logistics Research Team at Michigan State University (1995) in their large scale investigation found 17 universal logistics capabilities. Subsequently, these capabilities were categorized into competencies such as positioning, integration, agility, and measurement. Morash et al. (1996) categorized logistics capabilities into two major categories. The first category underscored the outside dimensions of a firm viz. customer, customer interfaces, and goals and objectives. This is referred to as the demand-oriented or the customer-oriented approach.

It comprised four logistics capabilities: presale customer service, post-sale customer service, delivery speed, and responsiveness. The second category is related to a firm's operational capabilities and is labeled the supply-oriented or the operations-oriented approach. It comprised of three supply-oriented capabilities: widespread distribution coverage/availability, selective distribution coverage, and low total cost distribution. Studies have found different classification logistics capabilities. Mentzer et al. (2004) classified logistics capabilities into demand management interface capabilities (also known as customer focus capabilities), supply management interface capabilities, information management capabilities and coordination capabilities. While demand management interface capabilities target to fulfill the requirements of different niches of customer segments through providing different products and services; supply management interface capabilities targets to achieve total cost minimization in supply of 
raw materials and distribution of finished goods (Morash et al., 1996; Zhao et al., 2001). Information management capabilities aim for gathering, analyzing and distributing routine and non-routine information both inside and outside the firm through appropriate infrastructure (Zhao et al., 2001; Mentzer et al., 2004).Coordination capabilities ensures that all interdependent logistics activities are appropriately aligned (Mentzer et al, 2004).To this existing classification, Esper et al. (2007) added two complementary logistics capabilities: integration capability and measurement capability. While integration capability aims to achieve a state of unity of efforts among inter-organizational elements; measurement capability is all about the extent to which a firm monitors its internal and external operations (Holmberg, 2000; Daugherty et al., 1998). Another important step was taken by Stank et al. (2005) in this arena through incorporating customer focus, time management and evaluation perspectives in logistics capabilities.

Studies have explored interfaces of logistics capabilities in realms of strategy and performance. Lynch et al. (2000) investigated the effect of logistics capabilities and strategy on firm performance. Their study revealed that logistics capabilities do exert a positive influence on performance when appropriately aligned with strategy. In a similar context, Zhao et al. (2001) found significant influences of customer focused capabilities and information focused capabilities on firm performance. While studies have assumed a firm's capability to outsource its logistics activities do also have a significant influence in the interface of capabilities and firm performance in online markets; it was observed that logistics outsourcing is no way related with its logistics capability in influencing firm performance (Cho et al., 2008).

Logistics capabilities have been consistently focused in improving the supply chain performance (Bowersox et al., 1999; Lynch et al., 2000; Stank et al.,2005; Sandberg \&
Abrahamsson,2011; Gligor \& Holcomb,2012). Further recent research posits that logistics capabilities, as an integral part of supply chain management, contributes greatly for the development of supply chain capabilities (Gligor \& Holcomb,2012; Gligor \& Holcomb,2014). Logistics is a specialized part if supply chain management. While logistics stresses on the transportation and movement of goods; supply chain management focuses on the effective coordination among different entities and thus encompasses multiple organizations compared to logistics (Mentzer et al.,2004). Hence, integrated logistics capabilities and supply chain integration are conceptually and fundamentally different. Integrated logistics capabilities are aimed more towards unifying the individual firm level logistics capabilities whereas supply chain integration is essentially philosophy spanning across multiple organizations that includes integrated logistics capabilities as a specialized part. Therefore, the influence of logistics capabilities in the development of supply chain capabilities must be investigated. Logistics capabilities, hence must be integrated for development of supply chain capabilities. The current study defines integrated logistics capabilities as the collective logistics capabilities resulting from the unison of individual firm level logistics capabilities and having the capacity to generate supply chain level capabilities. The difference between logistics capabilities and integrated logistics capabilities is evident. While logistics capabilities refer to individual firm level capabilities; integrated logistics capabilities result from the accumulation or summation of all such firm level logistics capabilities at the supply chain level. Further, supply chain capabilities refer Gligor and Holcomb (2012) have utilized integrated logistics capabilities as a precursor for development of agility at the conceptual level while Gligor and Holcomb (2014) empirically found positive influence of behavioral elements of cooperation, communication and coordination on integrated logistics 
capabilities that result in positive performance implications. In this study we further enrich the literature by exploring the influence of other two dominant relational attributes of trust and commitment and respond to the research call of Gligor and Holcomb (2014).

Logistics capabilities also have the potential to create significant competitive advantage through appropriate deployment of operational and dynamic capabilities when appropriately complemented with IT infrastructure and systems (Sandberg and Abrahamsson, 2011). Therefore, the generation of higher order capabilities specifically dynamic capabilities like agility, resilience and robustness mandates the appropriate support of IT integration and associated capabilities. Accordingly, our study considers IT integration as a contingent variable for the contributions of trust and commitment for developing integrated logistics capabilities.

\section{SC Capabilities: SC Agility, SC resilience and $S C$ robustness}

Within the relational view of RBV (i.e. resource based view); SC agility, SC resilience and SC robustness are being posited as dynamic capabilities developed through the integration of individual firm level logistics capabilities in a supply chain. Studies have mostly discussed agility, robustness and resilience in isolated investigations rather than exploring them in a single study. Dubey et al. (2014) argued that agility and resilience both have a dominant influence on firm performance. However, they have not explored on the inter-relationship among agility and resilience. Azevedo et al. (2010) explored on a conceptual note the similarities and dissimilarities between agile and resilient approaches in managing the supply chain. They adopted a strategic perspective which underscored that these two approaches do share certain similarities in efficient supply chain management for e.g. both of these approaches aims to provide a proactive and positive response to environmental changes.
Along similar lines, Brandon-Jones et al. (2014) argued resilience and robustness as two different yet related constructs depending on whether a strategic or operational perspective is taken on them. In this context, Wieland and Wallenburg (2013) posited agility and robustness as two core components of supply chain resilience. Further, Durach et al. (2015) argued that there are two strategies for dealing with supply chain disruptions: proactive and reactive. While agility and resilience belongs to supply chains being reactive; robustness acts as a proactive strategy and hence different from the above two.

In this study, SC agility is the essential capability of supply chains to respond to market needs and fulfill the same (Swafford et al.,2008; Braunscheidel and Suresh, 2009). With the shift in competition from firm to supply chain (Christopher, 2000); firms are compelled to design their operations and strategies so as to meet customer needs profitably. In recent literature, Vinodh (2010) argued that agility is the dynamic capability that facilitates companies to quickly respond to customers' changing requirements. Therefore, SC agility is an important outcome as a performance metric; as the same measures the performance of a firm in the market place through suitably satisfying its customer's requirements. Therefore, SC agility is conceptualized in this study as an important performance outcome developed as a result of integration of logistics capabilities.

SC resilience is an essential supply chain capability, particularly in recent times of increased environmental uncertainties and supply chain disruptions (Wagner \& Bode, 2008).

A most recent and accepted definition of supply chain resilience was given by Ponomarov \& Holcomb (2009):

"The adaptive capability of the supply chain to prepare for unexpected events, responds to disruptions, and recovers from them by maintaining continuity of operations at the 
desired level of connectedness and control over structure and function".

Studies have found several antecedents to supply chain resilience: viz. collaborative relationships, agile characteristics, supply chain re-engineering and risk awareness (Christopher \& Peck, 2004); collaboration, flexibility, visibility and velocity (Juttner \& Maklan, 2011); structural, relational and cognitive factors (Johnson et al., 2013); knowledge management (Scholten et al.,2014). As firms need this capability to mitigate risk events, fight disruptions proactively and therefore may be used as an opportunity by firms to gain competitive advantage (Juttner \& Maklan, 2011); we posit SC resilience as an important performance outcome developed through integrated logistics capabilities in this investigation.

SC robustness and SC resilience are two terms that has been used interchangeably in the supply chain management literature. However, Wieland and Wallenburg (2013) conceptualized resilience as a composite of agility and robustness; while BrandonJones et al. (2014) clearly differentiated the concepts of resilience and robustness. Robustness is the ability of supply chains to sustain its normal operating function faced with internal or external disruptions (Brandon-Jones et al., 2014). Stonebraker et al. (2009) in their conceptualization of SC robustness focused on the ability to continue operations while prohibiting the negative influence of supply chain disruptions. Literature has argued that SC robustness needs to be defined more clearly in terms of conceptualization and operationalization (Vlajic et al., 2012; Natarajarathinam et al., 2009). Robustness needs to adapt for maintaining stability of structure during a disruption. BrandonJones et al. (2014) argued an example for explaining this:

"For example, many electronic firms qualify a second supplier and assign a small proportion (circa 5\% per annum) of spend. Qualifying and maintaining a second supplier might increase direct and indirect costs but provides responsive switching in the event of a disruption. This "fails safe mechanism" means that components of the system can adapt in response to specific perturbations while maintaining overall operating performance".

Therefore, in this investigation we conceptualize supply chain robustness as an important performance outcome of integrated logistics capabilities as it helps the supply chain to maintain its structure given a disruption. Our study adopts an "enabler - mechanism - outcome (performance)" paradigm. This way, the logistics integration capability is the mechanism that leads to SC capabilities (agility, resilience, and robustness). FabbeCostes and Jahre (2008) reviewed the effect of SC integration on firm performance and they found no significant effect of supply chain integration on financial performance. In line with this, we posit trust and commitment as enablers of the mechanism (i.e. integrated logistics capabilities) that results in supply chain capabilities e.g. agility, resilient and robustness as performance outcomes.

\section{Hypotheses Development}

\section{Trust \& Commitment}

While some studies examining the link between trust and commitment concluded that trust precedes commitment (Hess \& Story, 2005; Tan \& Lim, 2009), other studies implied that it is commitment (or feelings of loyalty to the organization) that in fact enhances the likelihood of trust (Wong \& Sohal, 2002). Others simply imply that trust and commitment both impact other organizational outcomes and as such have different antecedents (Iverson et al, 1996). However, the current study adopts the notion highlighted in commitment-trust theory. According to this theory, in a network of firms; unless firms can trust each other; they will not be willing to continue 
working with each other i.e. committed toward each other (Morgan \& Hunt, 1991; Naude \& Buttle, 2000; Wu \& Cavusgil, 2006; Rauyruen \& Miller, 2007). Accordingly, we posit that:

H1: Trust is positively associated with commitment.

\section{Trust and Integrated Logistics Capabilities}

Trust is one of the most cited relational resource and dimension of supply chain relationships (Fynes et al., 2004, 2005). Different approaches have been used to investigate the construct. The widely cited definition of trust found in supply chain literature is "the firm's belief that another company will perform actions that will result in positive actions for the firm, as well as not take unexpected actions for the firm, that would result in negative outcomes for the firm" (Anderson and Narus, 1990, p. 45). Different types of trust exist viz. contractual trust, competence trust and goodwill trust (Fynes et al., 2005a). Zaheer et al. (1998) further distinguished between interpersonal trust and inter-organizational trust. Moorman et al. (1993) refers to trust as the willingness to rely on an exchange partner in whom one has confidence. Morgan and Hunt (1991) referred to trust as "a firm's belief in its partner's trustworthiness and integrity". Pruitt (1981) defines trust as the belief that a party's word is reliable and that a party will fulfill its obligation in an exchange. This definition indicates a firm's willingness to collaborate. Zand(1972) argues that absence of trust will prohibit information exchange and will hamper joint problem efforts. In exchange relationships, the presence of trust will facilitate better stress management and adaptive capability (Williamson, 1985). Further the development of integrated logistics capabilities is contingent upon trust among the supply chain members. Unless the supply chain members trust each other; they will not be willing to form an effective integration of each other's capabilities. Accordingly, we posit that:
H2: Trust is positively associated with integrated logistics capabilities.

\section{Commitment and integrated logistics capabilities}

The willingness of trading partners to apply effort due to the relationship is referred to as commitment (Kwon \& Suh,2006). Quite frequently it indicates a firm's attempt to build a relationship that can be sustained in times of problems and contingencies (Gundlach et al.,1995) High levels of commitment develops the platform in which both parties to exchange can realize joint goals without any opportunistic behavior. Committed parties are willing to invest in transaction-specific assets, demonstrating that they can be relied upon to perform essential functions in the future (Anderson and Weitz, 1992). These investments help in arriving in stabilizing supply chain relationships and eliminate the uncertainty of continually searching and forming new relationships. There has been a positive relationship between commitment and relationship success (Mohr and Spekman, 1994). We also argue that unless the supply chain members are committed to work with each other; each firm in the supply chain will not be able to effectively integrate their firmlevel logistics capabilities with each other. The partners in a supply chain should be willing to continue supply chain relationships in order for effective integration to take place. Therefore, we posit that:

H3: Commitment is positively associated with integrated logistics capabilities.

\section{Integrated logistics capabilities and SC agility}

Logistics capabilities have contributed to improved performance ether directly (Zhao et al., 2001; Gligor \& Holcomb, 2014) or through creation of other supply chain capabilities (e.g. supply chain agility) leading to sustained competitive advantage (Gligor \& Holcomb, 2012).Supply chain agility enables a supply chain to respond in a speedy manner to customer needs (Swafford et al.,2008).Although different 
definitions of agility exists in the supply chain literature; most of them underscores the common notion of responding at rapid pace (Nagel \& Dove,1991;Goldman et al.,1995; Gunasekaran, 1999;Gunasekaran \& Yusuf,2002;Swafford et al.,2006; Braunscheidel and Suresh, 2009).However, the prevalence of agility in supply chains recently are of immense importance. This is due to an increased competition in the market place compelling firms to use their resources for developing capabilities for responding to customer's dynamic needs. Since logistics is an integral part of supply chain management; we argue that any capabilities developed at the supply chain level calls for unification of individual logistics capabilities of the firms within the supply chain. This leads us to our next hypotheses:

H4: Integrated logistics capabilities are positively associated with SC agility.

\section{Integrated logistics capabilities and $S C$ resilience}

SC resilience aims for the restoration of supply chain operations when faced with a disruption (Christopher \& Peck, 2004; Ponomarov \& Holcomb, 2009). Resilience in supply chains are mostly underscored as an adaptive capability that is generated suitably through investment of a firm's other resources and capabilities in response to an environmental threat(Ponomarov \& Holcomb,.2009; Carvalho et al.,2012).Further, it was noted in allied studies that resilience can be developed well before a crisis if there is effective collaboration among the supply chain entities (Juttner \& Maklan,2011). Also a supply chain can mitigate a risk event to if the design of supply chain itself has taken some proactive measures (Christopher \& Peck, 2004). The definition of resilience holds the notion that all disruptions cannot be prevented in a complete manner; neither every form of loss created by a disruption can be recovered complete (Juttner \& Maklan, 2011). Further recent studies have underscored that resilience can increase customer value and firm reputation (Wieland \& Wallenburg, 2013). However, studies have argued that integration of resources and capabilities are an integral part of efficient supply chain management (Esper and Defee 2010). We posit in the line with established literature that unification of individual firm level capabilities is required for developing resilience, being posited as an overall supply chain capability. Individual firms in a supply chain therefore should contribute for efficient unification. Accordingly, following the argument used in developing $\mathrm{H} 4$, we posit that:

H5: Integrated logistics capabilities are positively associated with SC resilience.

\section{Integrated logistics capabilities and SC robustness}

SC robustness is frequently dealt with supply chain SC resilience (Carvalho et al., 2012; Wieland \& Wallenburg, 2013). Supply chain robustness is defined as the ability of the supply chain to maintain its function despite internal or external disruptions (cf. Kitano, 2004). Therefore, robustness as a supply chain capability focuses on sustaining operations while resilience aims for restoring operations. Robustness can help a firm to provide the minimal damage to its structure and function as it tries to maintain the operational structure. Robust systems need to change during a disruption for maintaining structure (Kitano, 2004). This draws the fine distinction between the two terms of resilience and robustness. However, to develop such a supply chain capability that can sustain its operation during an environmental uncertainty, the individual firms within a supply chain must make attempts to integrate or unify their individual logistics functions and capabilities. We argue that without effective unification of individual firm level capabilities at the supply chain level, supply chains can't develop the ability to withstand disruptions. Accordingly, we posit that:

H6: Integrated logistics capabilities are positively associated with SC robustness. 


\section{Moderating Role of IT Integration on Trust, Commitment and Integrated Logistics Capabilities}

IT Integration refers to the extent to which a firm links its IT to those of business partners, helping the partners to exchange information, communicate, and establish collaborative relationships (Rai et al., 2006; Chen et al., 2015). In the current context, this becomes more vital as the relationship of trusts among supply chain partners with those of integrated logistics capabilities are positively complemented with effective IT integration capabilities of the focal firm. As the focal firm can link its systems with those of its business partners in a supply chain; it stands in a much better position to exchange real time information and developing collaborative relationships. This will aid in enhancing trust among supply chain partners along with incrementing the willingness of each and every partner to continue supply chain relationships for a considerable time i.e. increasing the commitment too. Through effective information sharing firms will be in a position to increase transparency of operations in a supply chain thereby helping partners to trust each other and be committed towards effective execution of supply chain relationships (Wu et al, 2014; Ganesh et al., 2014). This will help every partner in the supply chain to integrate their individual level logistics capabilities with that of each other at the supply chain level. Hence we posit that:

H7a: IT integration positively moderates the relationship between trust and integrated logistics capabilities.

H7b: IT integration positively moderates the relationship between commitment and integrated logistics capabilities.

Figure 1 below shows the theoretical model with the proposed hypotheses.

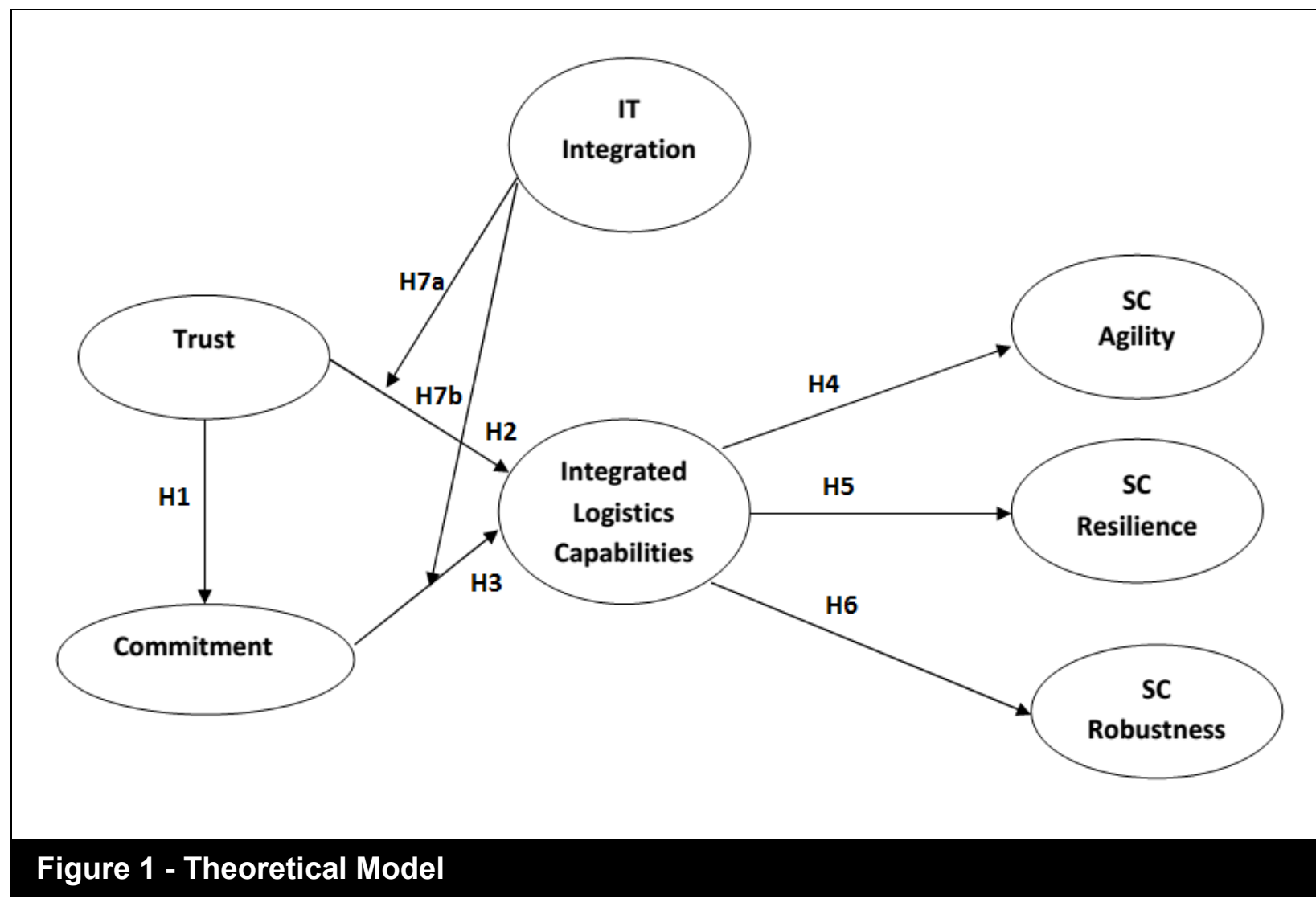

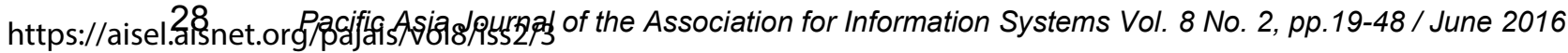




\section{Methodology}

\section{Data collection}

The unit of analysis adopted in this investigation was at the level of a manufacturing plant and its constituent upstream suppliers. Prior research has indicated that this unit of analysis provides a detailed understanding of how supply chain design affects performance (Bozarth et al., 2009; c.f. Naor, Linderman \& Schroeder, 2010). The data was collected through an online survey. The survey instrument was pretested by administering it to a small sample of supply chain managers drawn from a contact list that was purchased from a market research firm that specializes in providing business contacts and allied services (the firm wanted to remain anonymous). Some of the measurement items were adapted to suit the context based on the feedback received during pretesting phase. The final list of logistics, supply chain and purchasing managers were chosen randomly from the aforesaid contact list. The list comprised of professionals working mostly in senior designations in the Indian subcontinent in different industries. The surveyed respondents were asked to respond based on their expertise in their respective manufacturing firms. The surveyed respondents were having at least 3-4 years of experience in their respective areas. Table I gives the descriptive statistics of the sample frame.

\section{Table 1 - Descriptive Statistics of Sample Frame}

\begin{tabular}{|c|c|c|}
\hline Title & Number & Percentage \\
\hline \multicolumn{3}{|l|}{ Annual Sales Revenue } \\
\hline Under $1000 \mathrm{Cr}$ & 30 & 16.39 \\
\hline $1100-2500 \mathrm{Cr}$ & 36 & 19.67 \\
\hline $2600-5000 \mathrm{Cr}$ & 28 & 15.33 \\
\hline $5100-10000 \mathrm{Cr}$ & 24 & 13.11 \\
\hline $11000-25000 \mathrm{Cr}$ & 34 & 18.57 \\
\hline Over $25000 \mathrm{Cr}$ & 31 & 16.93 \\
\hline Total & 183 & 100 \\
\hline \multicolumn{3}{|l|}{ No of employees } \\
\hline $0-50$ & 38 & 20.76 \\
\hline $51-100$ & 26 & 14.2 \\
\hline $101-200$ & 40 & 21.87 \\
\hline $201-500$ & 43 & 23.49 \\
\hline $501-1000$ & 24 & 13.13 \\
\hline $1001+$ & 12 & 6.55 \\
\hline Total & 183 & 100 \\
\hline \multicolumn{3}{|l|}{ Industry Sector } \\
\hline Automobiles & 17 & 9.28 \\
\hline Electrical equipment & 29 & 15.84 \\
\hline Textile & 15 & 8.19 \\
\hline Paper Products & 26 & 14.2 \\
\hline Wood Products & 16 & 8.79 \\
\hline Chemicals & 32 & 17.48 \\
\hline Furniture & 14 & 7.65 \\
\hline Plastic Products & 34 & 18.57 \\
\hline Total & 183 & 100 \\
\hline
\end{tabular}


The first round of survey invitation was sent in the first week of January, 2014 via email. This was followed by two reminders, each within a gap of two weeks after the preceding survey invitation. This was followed up with two reminders, each within a gap of two weeks after the preceding survey invitation. A total of 1078 emails were sent out. Out of these, 84 emails were returned as undeliverable. 204 partially complete responses were received, giving a response rate of $20.52 \%$ (204/994). However, for the final analysis we retained only complete responses. Thus, the final sample size was 183 with a final response rate of $18.41 \%(183 / 994)$.

\section{Non-Response Bias}

We tested for the non-response bias by comparing the early and late respondents (Armstrong and Overton, 1977). There were no significant mean differences between these two groups on key measures such as firm size and industry affiliation.

\section{Common Method Bias}

Since we collected from a single respondent per firm; common method may be a problem. Hence an assessment of common method bias was deemed necessary. Analysis of Harmon's single-factor test of common method bias (Podsakoff et al., 2003) showed 7 factors with Eigen values above 1 , explaining $71.5 \%$ total variance. The first factor explained $32.6 \%$ of the variance, which is not the majority of the total variance. Again we resort to a second test of common method bias; we applied confirmatory factor analysis to Harman's single-factor model (Flynn et al., 2010). The model's fit indices of chi-sq/df $=11.5, \mathrm{NNFI}=$ 0.11.5, NNFI= 0.43, $\mathrm{CFI}=0.54$ and RMSEA $=0.19$ were predominantly worse than those of the measurement model suggesting that single factor model is not acceptable; thus the common method bias is negligible.

\section{Survey Instrument}

The current study adapted the established scales of the constructs used in the theoretical model. The measures were suitably adapted (wherever needed) to suit the context. A total of 26 survey items (shown in Appendix-1) were used to measure endogenous and exogenous variables in the study.

\section{Endogenous Variables}

The endogenous variables in the current investigation were integrated logistics capabilities, SC agility, SC resilience and SC robustness. Integrated logistics capabilities were measured using five items that enquired respondents if their supply chain members have mutual accepted goals for efficient logistics management; share logistics capability forecasts with one another at least once in a quarter; exchange demand information frequently (at least once a month); reduced formal organization structure for improved integration of logistics operations. The above items to measure integrated logistics capabilities were suitably adapted from Gligor \& Holcomb (2014). SC agility was measured with three indicators. The three items enquired respondents if their supply chain members share a high level of integrity among themselves. It further enquired if the supply chain members are dependable and whether they can be relied upon for help in crisis times. These items for measuring SC agility were suitably adapted from Blome et al. (2013).SC resilience was measured using four items. These enquired respondents if their supply chain can quickly restore material flow following a disruption; can efficiently deal with disruptions; can quickly restore its normal operating performance and is well prepared for mitigating disruptions. These items for measuring SC resilience were suitably adapted from Brandon-Jones et al. (2014). SC robustness was measures using four items that enquired respondents if their supply chain can continue its operations despite of a disruption; can successfully meet demands 
of its customers; can carry out its normal function even after a disruption and the supply chain is able to meet its target without huge deviations. These items for measuring SC robustness were suitably adapted from Brandon-Jones et al. (2014). All the measurement items were operationalized on a 1 to 7 Likert scale (1=Strongly Disagree; 4=Neutral and 7=Strongly Agree).

\section{Exogenous Variables}

The exogenous variables in the current investigation are Trust and Commitment. Trust was measured with three indicators that enquired the respondents if their supply chain members share a high level of integrity; if they can be relied upon for help during disruptions and if they trust each other completely. These scale items for measuring trust were suitably adapted from Fynes et al. (2005). Commitment was measured with three items that enquired respondents if their firm is totally dedicated for maintaining healthy relationships with their key suppliers; if their firm would like to sustain its supply chain relationships; if their firm delivers the maximum effort for maintaining its supply chain relationships. These scale items for measuring commitment were suitably adapted from Morgan \& Hunt (1991) and Fynes et al. (2005). All the measurement items were operationalized on a 1 to 7 Likert scale (1=Strongly Disagree; 4=Neutral and 7=Strongly Agree).

\section{Control Variables}

The current study incorporates two control variables before testing for the proposed relationships in line with recent investigations (Wagner \& Neshat, 2011; Brandon-Jones et al., 2014). They were firm size and environmental dynamism. Firm size was measured by the no of employees and large firms (as found in Wagner \& Neshat, 2011) were more susceptible to disruptions. Environmental dynamism was included to level out the effects of disruption across industry segments such that they became comparable (Brandon-Jones et al.2014). The items for measuring environmental dynamism was anchored on a 1 to 5 likert scale where 1=slow and $5=$ rapid with indicators reflecting pace of change in the industry for product/service introduction, operating processes, customer tastes/preferences and research and development.

\section{Moderating Variable}

It integration was included as the moderating variable in this investigation. The items for measuring IT integration were suitably adapted from Rai and Tang (2010) and was operationalized on a 1 to 7 Likert scale (1=Strongly Disagree; $4=$ Neutral and $7=$ Strongly Agree).

\section{Analysis \& Results}

\section{Measure Assessment}

The current study employed Partial Least Squares for scale validation and hypothesis testing. We followed the guidelines given for PLS usage and reporting in operations management research by Peng and Lai (2012). PLS is a structural equation modeling based methodology that deploys a component based approach for estimating the parameters. The benefit of using PLS extends from allowing the researcher to model formative constructs to estimating the required parameters with a minimal sample size. For PLS, the required sample size is ten times the number of indicators of the largest construct present in a theoretical model. As PLS does not provide a significance test or interval estimation, a bootstrapping analysis was conducted with 200, 500 and 1000 sub-samples (as suggested by Peng and Lai, 2012) for calculating the path co-efficient, statistical significance and allied parameters. The magnitude and significance of the structural paths were consistent. The procedure was executed in two steps. First, reliability and convergent validity was assessed. The second step assessed the discriminant validity. 
Table 2 shows the measures with item loadings and corresponding t-stats. Further Table 3 shows the average variance extracted (AVEs), Cronbach's alpha and composite reliability for each construct. The study first assessed reliability using the criterion, Cronbach's alpha larger than 0.7 (Chin, 1998). Convergent validity was next assessed using multiple criteria: (1) item loading larger than 0.70 and statistical significance, (2) composite construct reliability larger than 0.80 and (3) average variance extracted (AVE) larger than 0.50 (Fornell and Larcker, 1981). Further, discriminant validity was assessed using the criterion: the square root of AVE for each construct greater than its correlations with all other constructs (Fornell and Larcker, 1981). As indicated in Table 2 and 3, standardized item loadings range from 0.730 to 0.960 , composite reliabilities range from 0.911 to 0.959 , and average variance extracted (AVE) values range from 0.746 to 0.887. In Table 4, the square root of AVE for each construct is larger than its correlations with all other constructs. Hence, these results show a highly acceptable level of reliability, convergent and discriminant validity. In addition, we have included Table 5 showing cross loadings as another quality criterion.

\section{Structural Model Assessment and Hypotheses Testing}

Partial Least Squares was used as the methodology for measurement and structural model assessment followed by hypotheses testing. We used SmartPLS 2.0.M3 to estimate our research model. Before that we used several guidelines in line with Peng and Lai (2012) to assess the structural model.

We assessed the predictive relevance of our model by using the blindfolding procedure of SmartPLS 2.0.M3. StoneGeisser's $\mathrm{Q}^{2}$ (or construct cross-validated redundancy of SmartPLS 2.0.M3) of dependent variables are often used to ascertain predictive relevance. The Stone-
Geisser's $\mathrm{Q}^{2}$ of dependent variables in our model were $0.720,0.504,0.559,0.557$, 0.569 of commitment, integrated logistics capabilities, SC agility, SC resilience and SC robustness respectively, indicating acceptable predictable relevance $\left(Q^{2}>0\right.$ indicates acceptable predictable relevance).We also assessed the effect of the predictor constructs i.e. trust, commitment and IT integration on integrated logistics capabilities using Cohen $f^{2}$.Table 8 shows the relative effect sizes using Cohen $f^{2}$ as 0.52 for trust, 0.46 for commitment and 0.37 for IT integration. According to Cohen (1988), $f^{2}$ values of $0.35,0.15$, and 0.02 are considered large, medium, and small, respectively. Hence considering the effect sizes, we conclude that trust, commitment and IT integration has significant effect as predictors of integrated logistics capabilities. Although IT integration was used as a moderator; but for doing so it must have a significant relationship with the dependent variable in question i.e. integrated logistics capabilities.

Regarding overall quality of the research model, Peng and Lai (2012) though suggested to calculate a global Goodness of Fit Index as proposed by Tenenhaus et al. (2005); later investigations shows that this a not a valid fit measure and as such (Henseler and Sarstedt., 2013). Further, it is suggested to rely more on the measures indicating the model's predictive capabilities (Henseler et al., 2012). Still as a best practice we calculated GOF:

$\sqrt{\text { average communality }} \times \sqrt{\text { average } R^{2}}=$ $\sqrt{0.782} \times \sqrt{0.195}=0.391$.

This goodness of fit index considers the quality of the complete measurement model in terms of average communality and the quality of the complete structural model in terms of average R-square. The average of communality is computed as a weighted average of all the communalities using weights as the number of manifest variables in each construct with at least two manifest variables (Peng and Lai, 2012). 


\begin{tabular}{|c|c|c|}
\hline Construct & Loadings & t-value \\
\hline \multicolumn{3}{|l|}{ Trust } \\
\hline Our supply chain members trust each other completely. & 0.865 & 20.895 \\
\hline Our supply chain members can be counted on to help us. & 0.918 & 48.324 \\
\hline Our supply chain members have a high level of integrity. & 0.881 & 25.774 \\
\hline \multicolumn{3}{|l|}{ Commitment } \\
\hline Our firm is totally dedicated to its relationship with supply chain members. & 0.933 & 39.900 \\
\hline Our firm wants to pursue our supply chain relationships indefinitely. & 0.960 & 88.117 \\
\hline $\begin{array}{l}\text { Our firm delivers its maximum effort for maintaining its supply chain } \\
\text { relationships. }\end{array}$ & 0.933 & 45.324 \\
\hline \multicolumn{3}{|l|}{ Integrated Logistics Capabilities } \\
\hline $\begin{array}{l}\text { Our supply chain members have mutually accepted goals for managing their } \\
\text { logistics activities. }\end{array}$ & 0.743 & 10.440 \\
\hline $\begin{array}{l}\text { Our supply chain members regularly (at least once a quarter) share logistics } \\
\text { capacity forecasts with each other. }\end{array}$ & 0.884 & 36.635 \\
\hline $\begin{array}{l}\text { Our supply chain members successfully integrate logistics operations with each } \\
\text { other. }\end{array}$ & 0.802 & 12.823 \\
\hline $\begin{array}{l}\text { Our supply chain members frequently (at least once a month) exchange } \\
\text { demand information with each other for effective logistics operations planning. }\end{array}$ & 0.862 & 22.799 \\
\hline $\begin{array}{l}\text { Our supply chain members reduced formal organizational structure to enable } \\
\text { more integration of our respective logistics operations. }\end{array}$ & 0.807 & 15.102 \\
\hline \multicolumn{3}{|l|}{ SC Agility } \\
\hline $\begin{array}{l}\text { Our supply chain members are able to adapt our services and/or products } \\
\text { sufficiently fast to new customer requirements }\end{array}$ & 0.841 & 18.302 \\
\hline $\begin{array}{l}\text { Our supply chain members are able to react sufficiently fast to new market } \\
\text { developments }\end{array}$ & 0.886 & 25.074 \\
\hline $\begin{array}{l}\text { Our firm's supply chain is able to react to significant increases and decreases in } \\
\text { demand as fast as required by the market }\end{array}$ & 0.889 & 20.825 \\
\hline $\begin{array}{l}\text { Our firm's supply chain is able to react adequately fast to supply-side changes } \\
\text { e.g. delivery failures etc. }\end{array}$ & 0.846 & 13.884 \\
\hline \multicolumn{3}{|l|}{ SC Resilience } \\
\hline Our firm's supply chain can quickly restore its material flow & 0.769 & 8.274 \\
\hline $\begin{array}{l}\text { Our firm's supply chain will not take longer time to restore normal operating } \\
\text { performance }\end{array}$ & 0.919 & 18.849 \\
\hline Our firm's supply chain can efficiently deal with disruptions & 0.925 & 17.049 \\
\hline $\begin{array}{l}\text { Our firm's supply chain is well prepared for mitigating the consequences of } \\
\text { disruptions }\end{array}$ & 0.842 & 9.468 \\
\hline \multicolumn{3}{|l|}{ SC Robustness } \\
\hline Our firm's supply chain can continue its operations when faced with a disruption. & 0.730 & 5.214 \\
\hline $\begin{array}{l}\text { Our firm's supply chain would be able to meet customer demand in spite of a } \\
\text { disruption. }\end{array}$ & 0.925 & 11.524 \\
\hline Our firm's supply chain performance would not deviate significantly from targets. & 0.875 & 12.488 \\
\hline Our firm's supply chain would be able to carry out its normal functions. & 0.925 & 11.604 \\
\hline \multicolumn{3}{|l|}{ IT Integration } \\
\hline Our firm transfers data with our suppliers & 0.949 & 52.147 \\
\hline $\begin{array}{l}\text { Our firm connects our systems with our supplier systems, which allows for real } \\
\text { time sharing of information }\end{array}$ & 0.936 & 51.517 \\
\hline $\begin{array}{l}\text { Our firm combines information across different suppliers to support decision } \\
\text { making }\end{array}$ & 0.928 & 39.586 \\
\hline
\end{tabular}




\begin{tabular}{|l|c|c|c|c|c|}
\hline Table 3 - AVE, Composite Reliability and Cronbach's Alpha of Constructs \\
\hline Construct & Items & $\begin{array}{c}\text { Item } \\
\text { Loadings }\end{array}$ & $\begin{array}{c}\text { Composite } \\
\text { reliability }\end{array}$ & AVE & $\begin{array}{c}\text { Cronbach's } \\
\text { Alpha }\end{array}$ \\
\hline Trust & 3 & $0.865-0.918$ & 0.917 & 0.788 & 0.865 \\
\hline Commitment & 3 & $0.933-0.960$ & 0.959 & 0.887 & 0.936 \\
\hline IT Integration & 3 & $0.928-0.949$ & 0.956 & 0.879 & 0.931 \\
\hline Integrated Logistics Capabilities & 5 & $0.743-0.884$ & 0.911 & 0.674 & 0.878 \\
\hline SC Agility & 4 & $0.841-0.889$ & 0.922 & 0.749 & 0.891 \\
\hline SC Resilience & 4 & $0.769-0.925$ & 0.917 & 0.746 & 0.887 \\
\hline SC Robustness & 4 & $0.730-0.925$ & 0.923 & 0.75 & 0.881 \\
\hline
\end{tabular}

\section{Table 4 - Discriminant Validity}

\begin{tabular}{|l|c|c|c|c|c|c|c|}
\hline & $\mathrm{X} 1$ & $\mathrm{X} 2$ & $\mathrm{X} 3$ & $\mathrm{X} 4$ & $\mathrm{X} 5$ & $\mathrm{X} 6$ & $\mathrm{X} 7$ \\
\hline Trust(X1) & $\mathbf{0 . 8 8 7}$ & & & & & & \\
\hline Commitment (X2) & 0.434 & $\mathbf{0 . 9 4 1}$ & & & & & \\
\hline IT Integration(X3) & 0.502 & 0.424 & $\mathbf{0 . 9 3 0}$ & & & & \\
\hline Integrated Logistics Capabilities (X4) & 0.521 & 0.486 & 0.442 & $\mathbf{0 . 8 2 1}$ & & & \\
\hline SC Agility (X5) & 0.417 & 0.373 & 0.471 & 0.468 & $\mathbf{0 . 8 6 5}$ & & \\
\hline SC Resilience (X6) & 0.285 & 0.201 & 0.271 & 0.351 & 0.391 & $\mathbf{0 . 8 6 3}$ & \\
\hline SC Robustness (X7) & 0.216 & 0.130 & 0.125 & 0.297 & 0.163 & 0.292 & $\mathbf{0 . 8 6 7}$ \\
\hline
\end{tabular}

\section{Table 5 - Cross loadings of the Items}

\begin{tabular}{|c|c|c|c|c|c|c|c|}
\hline & Trust & Commitment & $\begin{array}{c}\text { IT } \\
\text { Integration }\end{array}$ & $\begin{array}{c}\text { Integrated } \\
\text { Logistics } \\
\text { Capabilities }\end{array}$ & $\begin{array}{c}\text { SC } \\
\text { Agility }\end{array}$ & $\begin{array}{c}\text { SC } \\
\text { Resilience }\end{array}$ & $\begin{array}{c}\text { SC } \\
\text { Robustness }\end{array}$ \\
\hline AG1 & 0.248 & 0.167 & 0.226 & 0.525 & $\mathbf{0 . 8 4 1}$ & 0.293 & 0.171 \\
\hline AG2 & 0.415 & 0.381 & 0.493 & 0.359 & $\mathbf{0 . 8 8 6}$ & 0.331 & 0.183 \\
\hline AG3 & 0.422 & 0.414 & 0.493 & 0.326 & $\mathbf{0 . 8 8 9}$ & 0.328 & 0.104 \\
\hline AG4 & 0.415 & 0.412 & 0.511 & 0.339 & $\mathbf{0 . 8 4 6}$ & 0.425 & 0.086 \\
\hline CMT1 & 0.392 & $\mathbf{0 . 9 3 3}$ & 0.387 & 0.441 & 0.325 & 0.220 & 0.107 \\
\hline CMT2 & 0.416 & $\mathbf{0 . 9 6 0}$ & 0.405 & 0.445 & 0.325 & 0.147 & 0.104 \\
\hline CMT3 & 0.418 & $\mathbf{0 . 9 3 3}$ & 0.406 & 0.488 & 0.402 & 0.202 & 0.155 \\
\hline ILC1 & 0.419 & 0.405 & 0.425 & $\mathbf{0 . 8 0 7}$ & 0.355 & 0.227 & 0.266 \\
\hline ILC2 & 0.420 & 0.484 & 0.383 & $\mathbf{0 . 8 6 2}$ & 0.336 & 0.250 & 0.215 \\
\hline ILC3 & 0.397 & 0.460 & 0.366 & $\mathbf{0 . 8 8 4}$ & 0.395 & 0.301 & 0.251 \\
\hline ILC4 & 0.457 & 0.309 & 0.329 & $\mathbf{0 . 7 4 3}$ & 0.350 & 0.314 & 0.217 \\
\hline ILC5 & 0.448 & 0.339 & 0.317 & $\mathbf{0 . 8 0 2}$ & 0.473 & 0.346 & 0.269 \\
\hline IT2 & 0.574 & 0.398 & $\mathbf{0 . 9 4 9}$ & 0.371 & 0.408 & 0.226 & 0.085 \\
\hline IT3 & 0.579 & 0.442 & $\mathbf{0 . 9 3 6}$ & 0.437 & 0.479 & 0.258 & 0.099 \\
\hline ITI & 0.602 & 0.352 & $\mathbf{0 . 9 2 8}$ & 0.429 & 0.433 & 0.276 & 0.165 \\
\hline RES1 & 0.416 & 0.350 & 0.486 & 0.345 & 0.553 & $\mathbf{0 . 7 6 9}$ & 0.076 \\
\hline RES2 & 0.245 & 0.089 & 0.220 & 0.269 & 0.308 & $\mathbf{0 . 9 1 9}$ & 0.306 \\
\hline RES3 & 0.152 & 0.074 & 0.119 & 0.248 & 0.226 & $\mathbf{0 . 9 2 5}$ & 0.311 \\
\hline RES4 & 0.130 & 0.126 & 0.058 & 0.321 & 0.209 & $\mathbf{0 . 8 4 2}$ & 0.343 \\
\hline ROB1 & 0.277 & 0.270 & 0.228 & 0.297 & 0.256 & 0.101 & $\mathbf{0 . 7 3 0}$ \\
\hline ROB2 & 0.162 & 0.036 & 0.056 & 0.251 & 0.083 & 0.304 & $\mathbf{0 . 9 2 5}$ \\
\hline ROB3 & 0.105 & 0.078 & 0.066 & 0.217 & 0.111 & 0.329 & $\mathbf{0 . 8 7 5}$ \\
\hline ROB4 & 0.167 & 0.026 & 0.050 & 0.242 & 0.083 & 0.308 & $\mathbf{0 . 9 2 5}$ \\
\hline TR1 & $\mathbf{0 . 8 6 5}$ & 0.319 & 0.558 & 0.514 & 0.333 & 0.283 & 0.240 \\
\hline TR2 & $\mathbf{0 . 9 1 8}$ & 0.403 & 0.588 & 0.445 & 0.382 & 0.278 & 0.164 \\
\hline TR3 & $\mathbf{0 . 8 8 1}$ & 0.434 & 0.518 & 0.431 & 0.396 & 0.200 & 0.171 \\
\hline & & & & & & & \\
\hline
\end{tabular}


Further, our sample size of 183 is well above the minimum sample size requirement of 130 as determined by the " 5 times" rule of thumb (i.e. the no of observations should be minimum five times the number of indicators). Also the construct having the largest number of indicators in our model is integrated logistics capabilities with 5 measurement items. In this regard, applying the "10 times" the no of indicators of the construct (having the maximum indicators) in our model also deemed satisfactory. However, a statistical power analysis is required for a formal assessment of adequacy of the sample size. As shown in Table 6, the power of each path is much greater than the recommended minimum of 0.80 .

Finally, the study evaluated the robustness of PLS results by calculating the average of the items within each construct and subjected these average values to the OLS regression. The OLS regression results are largely consistent with the PLS results (refer. Table 6).

\section{Table 6 - OLS Regression Results and Power}

\begin{tabular}{|l|c|c|c|c|c|}
\hline \multirow{2}{*}{ Structural Estimates Path } & \multicolumn{2}{|c|}{ PLS Result } & \multicolumn{2}{c|}{ OLS Regression result } & \multirow{2}{*}{ Power } \\
\cline { 2 - 5 } & Coefficient & T-stat & Coefficient & T-stat & \\
\hline Trust --> Int. Log. Capabilities & 0.383 & 3.219 & 0.377 & 3.677 & 0.919 \\
\hline Trust --> Commitment & 0.434 & 3.894 & 0.427 & 3.555 & 0.947 \\
\hline $\begin{array}{l}\text { Commitment--> Int. Log. } \\
\text { Capabilities }\end{array}$ & 0.320 & 2.349 & 0.318 & 2.691 & 0.963 \\
\hline Int. Log. Capabilities --> SC Agility & 0.469 & 4.521 & 0.473 & 4.298 & 0.902 \\
\hline $\begin{array}{l}\text { Int. Log. Capabilities --> SC } \\
\text { Resilience }\end{array}$ & 0.352 & 4.144 & 0.361 & 4.662 & 0.938 \\
\hline $\begin{array}{l}\text { Int. Log. Capabilities --> SC } \\
\text { Robustness }\end{array}$ & 0.298 & 2.747 & 0.304 & 3.012 & 0.955 \\
\hline
\end{tabular}

For hypotheses testing, it was required to estimate the path coefficients and statistical significance for the dominant paths in the first place. Second, coefficient of determination (R-square) for endogenous variables was computed to assess their predictive power.

$\mathrm{H} 1$ posited a positive influence of trust on commitment and that was supported $(0.434$; $\mathrm{t}=3.894)$. The path representing the influence of trust on integrated logistics capabilities was found to be positive and significant $(0.383 ; \mathrm{t}=3.219)$ and hence found support for $\mathrm{H} 2$. H3 predicted a positive influence of commitment on integrated logistics capabilities and the corresponding path was positive and significant (0.320; $\mathrm{t}=2.349$ ). Hence $\mathrm{H} 3$ was supported. $\mathrm{H} 4, \mathrm{H} 5$ and $\mathrm{H} 6$ predicted a positive influence of integrated logistics capabilities on agility, resilience and robustness respectively which also found support with positive and statistically significant coefficients of 0.479 , 0.352 and 0.298 respectively. Hence $\mathrm{H} 4, \mathrm{H} 5$ and $\mathrm{H} 6$ was also supported.

Further, the empirical model accounted for explaining 18.8 percent of the variance in commitment, 35.6 percent in competitive integrated logistics capabilities, 22 percent in SC agility, 12.4 percent in SC resilience and 8.9 percent in SC robustness. Following Chin (1998), R-square values of $0.67,0.33$ and 0.19 suggests substantial, moderate and weak predictive power of the model under consideration. Our model with above stated R-square values explains moderate to strong predictive ability of the proposed model. Table 7 shows the average $R^{2}$, average communality and average redundancy. The average values clearly show the higher predictive relevance and quality of the research model. 


\section{Table $7-\mathbf{R}^{2}$, Communality, Redundancy, $\mathbf{Q}^{2}, f^{2}$ for the constructs}

\begin{tabular}{|l|c|c|c|c|}
\hline Construct & $\mathbf{R}^{\mathbf{2}}$ & Communality (AVE) & Redundancy & $\mathbf{Q}^{\mathbf{2}}$ \\
\hline Trust & ----- & 0.788 & ---- & ---- \\
\hline Commitment & 0.188 & 0.887 & 0.166 & 0.720 \\
\hline IT Integration & ----- & 0.879 & ---- & ---- \\
\hline Integrated Logistics Capabilities & 0.356 & 0.674 & 0.137 & 0.504 \\
\hline SC Agility & 0.220 & 0.749 & 0.148 & 0.559 \\
\hline SC Resilience & 0.124 & 0.746 & 0.085 & 0.557 \\
\hline SC Robustness & 0.089 & 0.752 & 0.061 & 0.569 \\
\hline Average & 0.195 & 0.782 & 0.119 & 0.582 \\
\hline
\end{tabular}

Moderating Role of IT Integration

$\mathrm{H} 7 \mathrm{a}$ and $\mathrm{H} 7 \mathrm{~b}$ discussed a positive moderation of IT integration on trust and integrated logistics capabilities; and commitment and integrated logistics capabilities linkages respectively. For testing the proposed moderation effects in Smartpls, we created two interaction terms viz. (Trust $\times I T$ integration) and
(Commitment $\times$ IT integration) and regressed on integrated logistics capabilities. The corresponding coefficients were found to be positive and significant as shown (ref. Table 8 ) in the summary of hypotheses testing below. Hence our proposed $\mathrm{H} 7 \mathrm{a}$ and $\mathrm{H} 7 \mathrm{~b}$ were supported. Figure 2 summarizes the hypotheses testing results in a structural model.

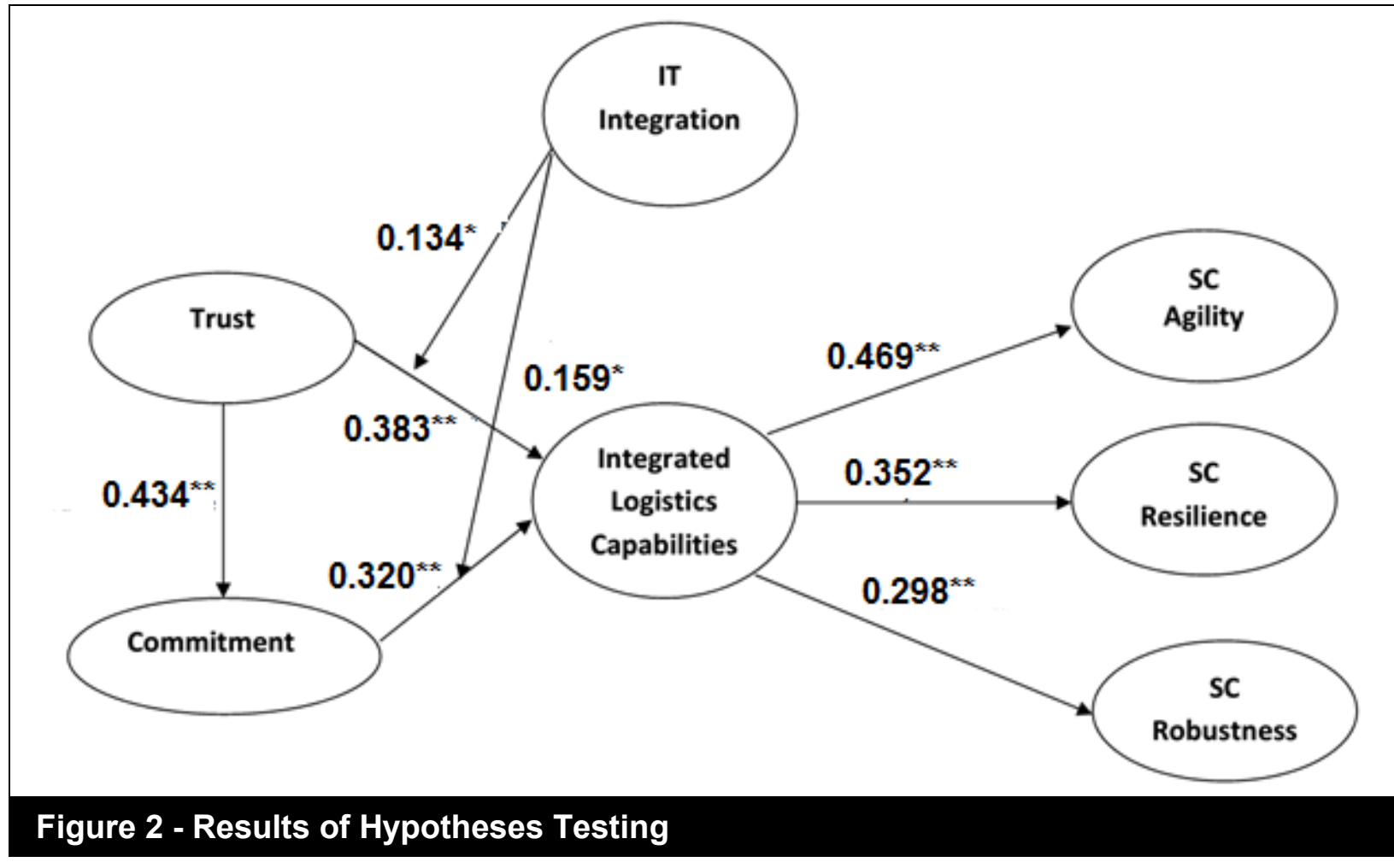

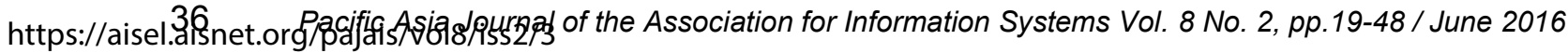




\begin{tabular}{|c|c|c|c|}
\hline \multicolumn{4}{|c|}{ Hypotheses Testing Results } \\
\hline $\begin{array}{c}\text { Hypotheses } \\
\text { No }\end{array}$ & Relationship & Std. Weights & Supported? \\
\hline $\mathrm{H} 1$ & TR--> CMT & 0.434 & Yes; $t=3.894$ \\
\hline $\mathrm{H} 2$ & TR--> ILC & 0.383 & Yes; $t=3.219$ \\
\hline $\mathrm{H} 3$ & CMT-->ILC & 0.320 & Yes; $t=2.349$ \\
\hline $\mathrm{H} 4$ & ILC--> AG & 0.469 & Yes; $\mathrm{t}=4.521$ \\
\hline $\mathrm{H} 5$ & ILC--> RES & 0.352 & Yes; $t=4.144$ \\
\hline $\mathrm{H} 6$ & ILC--> ROB & 0.298 & Yes; $t=2.747$ \\
\hline $\mathrm{H} 7 \mathrm{a}$ & Mod: IT Integration on TR--> ILC & 0.134 & Yes; $t=2.118$ \\
\hline $\mathrm{H} 7 \mathrm{~b}$ & Mod: IT Integration on CMT--> ILC & 0.159 & Yes; $\mathrm{t}=2.356$ \\
\hline \multicolumn{4}{|c|}{$\begin{array}{l}\text { TR }=\text { trust } \\
C M T=\text { commitment } \\
\text { ILC }=\text { integrated logistics capabilities } \\
\text { AG }=S C \text { agility } \\
\text { RES }=\text { SC resilience } \\
\text { ROB }=S C \text { robustness }\end{array}$} \\
\hline
\end{tabular}

\section{Alternate Model Testing}

Although we have obtained significant results for our proposed relationships and associated paths; we resort to an alternate model for exploring the inter-relationship between agility and resilience. Based on theoretical rationale, we argue that speed of response in supply chains is an intriguing requisite for developing resilience as a capability (Gligor et al., 2015). This is because the capability to respond in a speedy manner is a pre-requisite for being resilient. Hence we test for the influence of agility on resilience. Figure 3 shows the results of this proposed path (agility $\rightarrow$ resilience) in a structural model. It was found to be positive and significant $(0.353$; $t=2.451$ ).

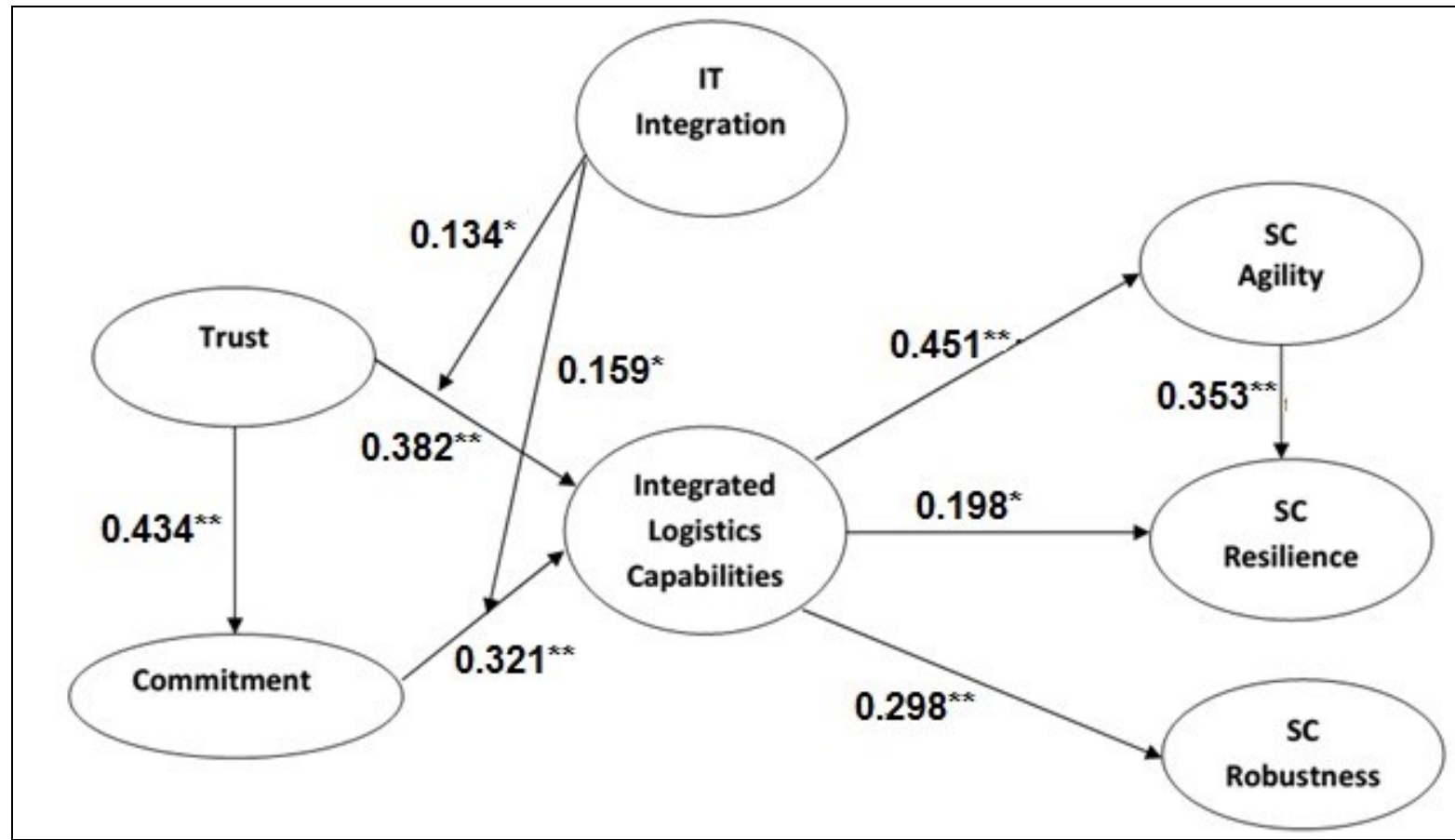

Figure 3 - Structural Model 


\section{Mediation Analysis}

A bootstrap method was employed (with $\mathrm{n}=1000$ bootstrap samples) to explore if commitment mediate the relationship between trust and integrated logistics capabilities along with other mediation analysis. Being a non-parametric resampling procedure, bootstrapping utilizes the input data to develop a numerical appropriation of the sampling distribution of a statistic. This means that a sample (with replacement) of size $n$ is taken from the full data set and the indirect effects are calculated in the resamples to develop the bootstrapping sampling distribution of indirect effects. Zhao et al. (2010) argued that point estimates of such indirect effects are significant in the case zero is not contained in the 95 percent confidence interval. If the confidence interval includes zero, the mediation hypothesis is rejected.

We resort to bootstrapping method for testing mediating effect for the following reasons: (1) the widely used method recommended by Baron and Kenny(1986) has low statistical power (MacKinnon et al., 2002), (2) the recommended Sobel test possess problems with standard errors associated with the significance test of indirect effects (Zhao et al., 2010) (3) bootstrapping can result in more statistical power, particularly when sample sizes are not large and (4) bootstrapping methods allow multiple mediators to be examined simultaneously to test whether an overall indirect effect exists (Preacher \& Hayes, 2008).

Table 9 contains the results for bootstrapping analysis. The mediating effect of commitment in the relationship between trust and integrated logistics capabilities was statistically significant at $p<0.05$ with 95 percent $\mathrm{Cl}=0.2479-0.3914$. The direct effect of trust on integrated logistics capabilities was also significant at alpha=0.05. Hence the results suggest the presence of both direct and indirect mediating role of commitment in the relationship of trust and integrated logistics capabilities. Further we also test for mediating role of integrated logistics capabilities in the relationship of trust and commitment with the supply chain capabilities of agility, resilience and robustness.

\section{Table 9 - Mediation Analysis}

\begin{tabular}{|c|c|c|c|c|c|c|c|c|}
\hline $\begin{array}{l}\text { Independent } \\
\text { variables (IV) }\end{array}$ & $\begin{array}{l}\text { Mediating } \\
\text { variable } \\
\text { (MV) }\end{array}$ & $\begin{array}{l}\text { Dependent } \\
\text { Variable } \\
\text { (DV) }\end{array}$ & $\begin{array}{c}\text { Effect } \\
\text { of IV } \\
\text { on MV } \\
\text { (a) }\end{array}$ & $\begin{array}{l}\text { Effect of } \\
\text { MV on } \\
\text { DV (b) }\end{array}$ & $\begin{array}{l}\text { Direct } \\
\text { Effect } \\
\text { (c') }\end{array}$ & $\begin{array}{c}\text { Indirec } \\
t \text { Effect } \\
\left(a^{*} b\right)\end{array}$ & $\begin{array}{l}\text { Total } \\
\text { effects } \\
\text { (c) }\end{array}$ & $\begin{array}{c}95 \\
\text { percent } \\
\text { Cl for } \\
\text { mean } \\
\text { indirect } \\
\text { effect }\end{array}$ \\
\hline Trust & Commitment & $\begin{array}{c}\text { Int. Logistics } \\
\text { Capabilities }\end{array}$ & $\underset{*}{0.7679^{*}}$ & $0.4569^{* *}$ & $0.345^{\star *}$ & $\begin{array}{c}0.3157^{*} \\
\end{array}$ & $\underset{*}{0.3502^{*}}$ & $\begin{array}{l}0.2479- \\
0.3914 \\
\end{array}$ \\
\hline Trust & $\begin{array}{c}\text { Int. Logistics } \\
\text { Capabilities }\end{array}$ & SC Agility & $\underset{*}{0.6947^{*}}$ & $0.4136^{* *}$ & 0.0471 & $\underset{*}{0.2951^{*}}$ & $\underset{*}{0.3422^{*}}$ & $\begin{array}{l}0.2134- \\
0.4135\end{array}$ \\
\hline Trust & $\begin{array}{l}\text { Int. Logistics } \\
\text { Capabilities }\end{array}$ & $\begin{array}{c}\text { SC } \\
\text { Resilience }\end{array}$ & $\underset{*}{0.7146^{*}}$ & $0.3897^{\star}$ & 0.0527 & $\underset{*}{0.2214^{*}}$ & $\begin{array}{c}0.2741^{*} \\
\end{array}$ & $\begin{array}{l}0.1934- \\
0.3248 \\
\end{array}$ \\
\hline Trust & $\begin{array}{c}\text { Int. Logistics } \\
\text { Capabilities }\end{array}$ & $\begin{array}{c}\text { SC } \\
\text { Robustness } \\
\end{array}$ & $0.7758^{*}$ & $0.3549^{* *}$ & 0.0322 & $\underset{*}{0.3511^{*}}$ & $\begin{array}{c}0.3833^{*} \\
\end{array}$ & $\begin{array}{l}0.2347- \\
0.4672 \\
\end{array}$ \\
\hline Commitment & $\begin{array}{l}\text { Int. Logistics } \\
\text { Capabilities }\end{array}$ & SC Agility & $0.8125^{*}$ & $0.4232^{* *}$ & 0.0413 & $\underset{* *}{0.3452^{*}}$ & $\underset{*}{0.3865^{*}}$ & $\begin{array}{l}0.1533- \\
0.3427\end{array}$ \\
\hline Commitment & $\begin{array}{l}\text { Int. Logistics } \\
\text { Capabilities }\end{array}$ & $\begin{array}{c}\text { SC } \\
\text { Resilience }\end{array}$ & $0.7654^{*}$ & $0.4621^{*}$ & 0.0657 & $\underset{*}{0.2914^{*}}$ & $\underset{*}{0.3571^{*}}$ & $\begin{array}{l}0.1637- \\
0.3679 \\
\end{array}$ \\
\hline Commitment & $\begin{array}{l}\text { Int. Logistics } \\
\text { Capabilities }\end{array}$ & $\begin{array}{c}\text { SC } \\
\text { Robustness }\end{array}$ & $\underset{*}{0.6245^{*}}$ & $0.3715^{*}$ & 0.0319 & $\underset{* *}{0.2649^{*}}$ & $\underset{*}{0.2968^{*}}$ & $\begin{array}{l}0.2566- \\
0.4139\end{array}$ \\
\hline
\end{tabular}


It is observed that for the mediating role of integrated logistics capabilities; all the indirect paths are statistically significant while direct paths are not. This strongly suggests that integrated logistics capabilities do act as an indirect mediator between (1) trust with agility, resilience and robustness and (2) commitment with agility, resilience and robustness.

\section{Theoretical and Managerial Implications}

\section{Empirical and Theoretical Implications}

The relational extension (i.e. relational view of firm) of RBV is concerned with the creation of competitive advantage. From this perspective, trust and commitment may be viewed as a bundle of relational resources that may lead to integrated logistics capabilities. These intangible resources fulfilled the criteria of "relationspecific assets" and as shown by the empirical results are a definite requisite for developing integrated logistics capabilities. Although we see both trust and commitment as giving rise to integrated logistics capabilities; trust can also give rise to commitment (Morgan \& Hunt, 1991) as shown by $\mathrm{H} 1$. Therefore, resources when combined or bundled, may lead to capabilities (Sirmon et al.,2007).Subsequently, capabilities may be leveraged or exploited for meeting opportunities and threats or contingencies (Sirmon et al.,2008). The current study explored the effects of integrating individual logistics capabilities of firms within a supply chain in developing supply chain capabilities. Further, our study has explored the influence of IT integration on important linkages of trust and commitment with integrated logistics capabilities. This further enhanced the domain of trust, commitment and supply chain relationship literature with IT.
Our study makes a number of important contributions. First this paper empirically addressed the research call suggested by Gligor \& Holcomb (2012) i.e. this study empirically proved that when logistics capabilities of individual firms within a supply chain are integrated appropriately; gives rise to supply chain capabilities. Gligor \& Holcomb (2012) explored this link conceptually and limited it to SC agility. We incorporated two more supply chain capabilities viz. SC resilience and SC robustness in addition to SC agility and investigated for the impact of integrated logistics capabilities on these. This is one of the first studies to empirically validate this conceptual link suggested by Gligor \& Holcomb (2012).

Secondly, our study further supported the difference between resilience and robustness in line with Brandon-Jones et al. (2014). Their study empirically established that resilience and robustness are discrete concepts. Our study further supported this as the measurement items loaded on expected constructs without any commonality.

Thirdly, our study is one of the first to investigate the impact of integrated logistics capabilities on three dominant supply chain capabilities viz. SC agility, SC resilience and SC robustness in an integrated model (Gligor and Holcomb, 2012; Azevedo et al., 2010; Brandon-Jones et al., 2014; Durach et al., 2015). The statistical significance of the corresponding coefficients suggests it is important for a firm to take appropriate measures along with other supply chain entities for integrating their individual logistics capabilities so as to generate dynamic capabilities like SC resilience and robustness in addition to agility so as to fight environmental contingencies. Agility will impart the firm with the ability to rapidly respond to dynamic needs of its customers and hence the integration of logistics capabilities can really help a firm gain competitive advantage in the market (Swafford et al.,2008).Further, resilience will help a firm to mitigate the negative effects of 
disruptions and hence it's a dominant requisite for today's firms among dynamic supply chain capabilities(Juttner \& Maklan,2011).Robustness will enable a supply chain to sustain its normal functions in the event of a disruption and hence served as a fruitful capability and outcome of integrated logistics capabilities (BrandonJones et al.,2014).

Fourthly, studies in supply chain have mostly considered performance dimensions like supply chain performance measured through customer order cycle time, customer order fill rate, inventory turnover etc. (Wagner \& Bode, 2008; Srinivasan et al.,2011) or firm performance measured through operational performance and relational performance (Blome et al.,2013; Gligor \& Holcomb,2014).However, the current investigation argued that an optimal supply chain performance often results due to certain dynamic capabilities that enables a firm to adapt to its changing environment and perform at an optimal level. Accordingly, the study considered the impact of three dominant and dynamic supply chain capabilities viz. agility, resilience and robustness.

Fifthly, our study addressed the research gap given by Gligor \& Holcomb (2014) viz. to investigate the influence of other relational attributes (apart from communication, cooperation and coordination) on integrated logistics capabilities. Accordingly, we have investigated the impact of trust and commitment (along with their interrelationship) on integrated logistics capabilities and found their effect to be pronounced.

Sixthly, by incorporating environmental (industry) dynamism as a control variable we have clearly segregated the effects it can have along with other exogenous variables on the respective endogenous variables. Environmental dynamism has considered most of the uncertainties reflecting pace of change in the industry for product/service introduction, operating processes, customer tastes/preferences and research and development.

Our mediation analysis has showed that integrated logistics capabilities does impact the relationship of the behavioral elements of trust and commitment in the development of agility, resilience and robustness. This is an important contribution of our empirical study thereby enriching the allied literature. Earlier studies urged for this research call (Gligor and Holcomb, 2012) and our exploration have successfully addressed the same. On theoretical grounds, this established that the behavioral elements, integrated logistics capabilities are interrelated with supply chain capabilities. Further, our study has considered the influence of IT integration on the proposed influences of trust and commitment on integrated logistics capabilities. This is another significant contribution of our study as IT integration enables a firm to connect its systems with those of their business partners and aids in joint decision making enhancing collaborative relationships (Chen et al., 2015). This is required further for the development of dynamic capabilities as they are required to adapt the associated firms to environmental changes. Our study as shown therefore that, with IT integration in place; firms in a supply chain can trust each other better and can be more committed towards unifying their individual logistics capabilities at the supply chain level for developing dynamic capabilities of agility, resilience and robustness.

\section{Managerial Implications}

This study offers several implications for supply chain and procurement managers. First, our findings indicate that supply chain managers should devise mechanisms and invest resources that can facilitate trust and commitment among supply chain members. Earlier researches have established trust and commitment as critical for supply chain relationship success (Kwon \& Suh, 2006). This study suggests managers to focus on developing more collaborative relationships based on trust and commitment for 
developing and integrating logistics capabilities. This will in turn facilitate the development of supply chain capabilities like agility, resilience and robustness enabling the firm to adjust to its dynamic conditions. Secondly, findings indicate that firms must work in a unified manner within a supply chain for effective integration of their logistics capabilities. Supply chain managers therefore arrange meetings with their supply chain partners regularly; invest after technologies to restore operations when faced with a disruption and robustness will enable a supply chain to sustain its operations despite of a disruption. So managers should understand the importance of these supply chain capabilities in harnessing the firm with a competitive advantage. This understanding will lead the way for strategic investments for development of logistics capabilities and supply chain capabilities, in turn. Further, managers and practitioners must invest for developing their IT infrastructure so as to enhance their ability to integrate the individual logistics capabilities of partnering firms at the supply chain level. This is to be aided with improved systems, hardware and software resources so that collaborative relationships can be improved with more effective joint decision making. Further as suggested by our mediating analysis, managers must ensure for developing integrated logistics capabilities as the same also impacts the manner in which trust and commitment ensures the development of supply chain capabilities of agility, resilience and robustness. Our study therefore suggested another significant contribution in the emerging area of robustness (Durach et al., 2015) by undersigning the trust, commitment and integrated logistics capabilities as likely factors to contribute to its development.

\section{Limitations and Directions for Future Research}

The limitations and probable areas are outlined below. Quite inherent in crosssectional survey design, the current investigation was limited by single respondent. While our research focused on the effects of trust and commitment as relational resources; future research can focus on including other such resources e.g. communication, cooperation and coordination (Gligor \& Holcomb, 2014) along with trust and commitment in an integrated model. Further research can also focus on incorporating the interrelationships among this relational resources and how this impact integrated logistics capabilities.In addition, future research can also focus on empirically exploiting the impact of individual logistics capabilities (as classified in different studies e.g. Mentzer et al., 2004) on integrated logistics capabilities and how the same impacts, in turn, the development of supply chain capabilities (Gligor \& Holcomb, 2012).This will guide supply chain managers in finding out the critical logistics capabilities and accordingly prioritize their resource investments.

Further, future research should exploit the moderating impact of variables e.g. supply base complexity (Brandon-Jones et al., 2014 ) etc. on the relationship between integrated logistics capabilities and each of the supply chain capabilities viz. agility, resilience and robustness. Future research can also investigate the effect of the three dimensions of social capital viz., cognitive, relational and structural (Johnson et al., 2013) on each of these supply chain capabilities viz. agility, resilience and robustness. Finally, future research should also investigate for other supply chain capabilities that can be considered as performance outcomes of integrated logistics capabilities. For e.g. this suggests for investigating the link between integrated logistics capabilities and supply chain flexibility etc. 


\section{References}

Amit, R. and Schoemaker, P. J. (1993). "Strategic assets and organizational rent." Strategic Management Journal, 14(1), pp. 33-46.

Anderson, J. C. and Narus, N. A. (1990). "A Model of Distributor Firm and Manufacturing Working Partnerships." Journal of Marketing, 54(1), pp. 42-58.

Anderson, E. and Weitz, B. (1992). "The Use of Pledges to Build and Sustain Commitment in Distribution Channels." Journal of Marketing Research, 29(2), pp. 18-34.

Armstrong, J. S. and Overton, T. S. (1977). "Estimating non response bias in mail surveys." Journal of Marketing Research, 34(2), pp. 396-402.

Azevedo, S. G., Carvalho, H., CruzMachado, V., \& Grilo, F. (2010, September). "The influence of agile and resilient practices on supply chain performance: an innovative conceptual model proposal." In Hamburg International Conference of Logistics (pp. 273-281).

Barney, J. (1991). "Firm Resources and Sustained Competitive Advantage." Journal of Management, 17(1), pp. 99-120.

Baron, R. M., \& Kenny, D. A. (1986). "The moderator-mediator variable distinction in social psychological research: Conceptual, strategic, and statistical considerations." Journal of personality and social psychology, 51(6), 1173.

Blome, C., Schoenherr, T. and Rexhausen, D. (2013). "Antecedents and enablers of supply chain agility and its effect on performance: a dynamic capabilities perspective." International Journal of Production Research, 51(4), pp. 12951318.

Bowersox, D.J., Stank, T.P. and Daugherty, P.J. (1999). "Lean launch: managing product introduction risk through response-based logistics." Journal of Product Innovation Management, 16(6), pp. 557-68.

Bowden, J., Dagger, T. and Elliott, G. (2015). Earning Customer Loyalty: The Role of Satisfaction, Trust, Delight, Commitment and Involvement. In Marketing in Transition: Scarcity, Globalism, \& Sustainability (pp. 362362). Springer International Publishing.

Bozarth, C. C., Warsing, D. P., Flynn, B. B. and Flynn, E. J. (2009). "The impact of supply chain complexity on manufacturing plant performance." Journal of Operations Management, 27(1), pp. 78-93.

Braunscheidel, M.J. and Suresh, N.C. (2009). "The organizational antecedents of a firm's supply chain agility for mitigation and response." Journal of Operations Management, 27(2), pp. 119-40.

Brandon-Jones, E., Squire, B., Autry, C. and Petersen, K. J. (2014). "Contingent Resource - Based Perspective of Supply Chain Resilience and Robustness." Journal of Supply Chain Management, 3(1), pp. 55-73.

Carvalho, H., Azevedo, S. G. and CruzMachado, V. (2012). "Agile and resilient approaches to supply chain management: influence on performance and competitiveness." Logistics Research, 4(2), pp. 49-62.

Chen, Y., Wang, Y., Nevo, S., BenitezAmado, J. and Kou, G. (2015). "IT capabilities and product innovation performance: The roles of corporate entrepreneurship and competitive intensity." Information Management, 52(6), pp. 643-657.

Chin, W.W., 1998. The partial least squares approach to structural equation modeling. In: Marcoulides, G.A. (Ed.), 
Modern Methods for Business Research. Lawrence Brlbaum Associates, Mahwah, NJ, pp. 295-336

Cho, J. J. K., Ozment, J. and Sink, H. (2008). "Logistics capability, logistics outsourcing and firm performance in an e-commerce market." International Journal of Physical Distribution \& Logistics Management, 38(5), pp.336359.

Christopher, M. (2000). "The agile supply chain-competing in volatile markets." Industrial Marketing Management, 29(1), pp. 37-44

Christopher, M. and Peck, H. (2004). "Building the resilient supply chain." The International Journal of Logistics Management, 15(2), pp. 1-14.

Christopher, M. (1994). Logistics and Supply Chain Management. Burr Ridge, IL : Irwin Professional.

Cohen, J. (1988). Statistical power analysis.

Council of Logistics Management (2003), available at: www.clm1.org

Daugherty, P.J., Stank, T.P. and Ellinger, A.E. (1998). "Leveraging logistics/distribution capabilities: the effect of logistics service on market share." Journal of Business Logistics, 19(2), pp. 35-52

Dubey, R., Ali, S. S., Aital, P., and Venkatesh, V. G. (2014). "Mechanics of humanitarian supply chain agility and resilience and its empirical validation." International Journal of Services and Operations Management, 17(4), pp. 367-384.

Durach, C. F., Wieland, A., and Machuca, J. A. (2015). "Antecedents and dimensions of supply chain robustness: a systematic literature review." International Journal of Physical Distribution \& Logistics Management, 45(2), pp. 118-137.

Dyer, J. H., and Singh, H. (1998). "The relational view: cooperative strategy and sources of inter-organizational competitive advantage." Academy of Management Review, 23(4), pp. 660679.

Esper, T.L., Fugate, B.S. and Davis-Sramek, B. (2007). "Logistics learning capability: sustaining the competitive advantage gained through logistics leverage." Journal of Business Logistics, 28(2), pp. 57-81

Esper, T. and Defee, C.C. (2010). "A Framework of Supply Chain Orientation." International Journal of Logistics Management, 21(2), pp. 161-79.

Fabbe-Costes, N. and Jahre, M. (2008). "Supply chain integration and performance: a review of the evidence." The International Journal of Logistics Management, 19(2), pp. 130 $-154$

Fornell, C., \& Larcker, D. F. (1981). "Structural equation models with unobservable variables and measurement error: Algebra and statistics." Journal of marketing research, 382-388.

Friman, M., Garling, T., Millett, B., Mattsson, J. and Johnston, R. (2002). "An analysis of international business-tobusiness relationship based on the commitment-trust theory." Industrial Marketing Management, 31(6), pp. 403-409.

Fynes, B., de Bu'rca, S. and Marshall, D. (2004). "Environmental uncertainty, supply chain relationship quality and performance." Journal of Purchasing \& Supply Management, 10 (4/5), pp.179-190.

Fynes, B., Voss, C., \& de Búrca, S. (2005). "The impact of supply chain relationship quality on quality performance." International Journal of Production Economics, 96(3), 339-354.

Fynes, B., de Bu'rca, S. and Voss, C. (2005a). "Supply chain relation-ship quality, the competitive environment 
and performance." International Journal of Production Research, 43(16), pp.3303-3320.

Fynes, B., Voss, C. and de Bu'rca, S. (2005b). "The impact of supply chain relationship dynamics on manufacturing performance." International Journal of Operations and Productions Management, 25 (1), pp. 6-19.

Fynes, B., De Burca, S. and Mangan, J. (2008). "The effect of relationship characteristics on relationship quality and performance." International Journal of Production Economics, 111(1), pp. 56-69.

Flynn, B. B., Huo, B., and Zhao, X. (2010). "The impact of supply chain integration on performance: a contingency and configuration approach." Journal of Operations Management, 28(1), pp. 58-71.

Ganesh, M., Raghunathan, S., and Rajendran, C. (2014). "The value of information sharing in a multi-product, multi-level supply chain: Impact of product substitution, demand correlation, and partial information sharing." Decision Support Systems, 58(1), pp. 79-94.

Garbarino, E., and Johnson, M. S. (1999). "The different roles of satisfaction, trust, and commitment in customer relationships." Journal of Marketing, 39(1), pp.70-87.

Gaur, A. S., Mukherjee, D., Gaur, S. S., and Schmid, F. (2011). "Environmental and Firm Level Influences on InterOrganizational Trust and SME Performance." Journal of Management Studies, 48(8), $1752-$ 1781.

Gligor, D. M. and Holcomb, M. C. (2014). "Antecedents and Consequences of Integrating Logistics Capabilities across the Supply Chain."
Transportation Journal, 53(2), pp. 211-234.

Gligor, D. M., and Holcomb, M. C. (2012). "Understanding the role of logistics capabilities in achieving supply chain agility: a systematic literature review." Supply Chain Management: An International Journal, 17(4), pp.438453.

Gligor, D. M., Esmark, C. L., \& Holcomb, M. C. (2015). "Performance outcomes of supply chain agility: when should you be agile?." Journal of Operations Management, 33, 71-82.

Goldman, S.L., Nagel, R.N. and Preiss, K. (1995). Agile Competitors and Virtual Organizations: Strategies for Enriching the Customer, Van Nostrand Reinhold, New York, NY.

Global Logistics Research Team at Michigan State University. (1995). World Class Logistics: The Challenge of Managing Continuous Change. Oak Brook, IL: Council of Logistics Management.

Goo, J. and Nam, K. (2007). "Contract as a source of trust-commitment in successful IT outsourcing relationship: an empirical study". Paper presented at 40th Annual Hawaii International Conference on System Sciences, Waikoloa, $\mathrm{HI}$.

Gunasekaran, A. (1999). "Agile manufacturing: a framework for research and development."International Journal of Production Economics, 62(1/2), pp. 87-105.

Gunasekaran, A. and Yusuf, Y.Y. (2002). "Agile manufacturing: a taxonomy of strategic and technological imperatives." International Journal of Production Research, 40(6), pp. 135785.

Gundlach, Gregory T., Ravi S. Achrol, and John T. Mentzer (1995). "The Structure of Commitment in 
Exchange." Journal of Marketing, 59(1), pp. 78-92.

Henseler, J., Ringle, C. M., \& Sarstedt, M. (2012). "12 Using partial least squares path modeling in advertising research: basic concepts and recent issues." Handbook of research on international advertising, 252.

Henseler, J., \& Sarstedt, M. (2013). "Goodness-of-fit indices for partial least squares path modeling." Computational Statistics, 28(2), 565580.

Hess, J., and Story, J. (2005). "Trust-based commitment: multidimensional consumer-based relationships." Journal of Consumer Marketing, 22(6), pp. 313-322.

Holmberg, S. (2000), "A systems perspective on supply chain measurements", International Journal of Physical Distribution \& Logistics Management, 30(10), pp. 847-868.

Iverson, R. D., Colin, S. and Erwin, P. J. (1996). "The role of employee commitment and trust in service relationships." Marketing Intelligence \& Planning, 14(3), pp. 36-44.

Johnson, N., Elliott, D. and Drake, P. (2013). "Exploring the role of social capital in facilitating supply chain resilience." Supply Chain Management: An International Journal, 18(3), pp. 324336.

Juttner, U., and Maklan, S. (2011). "Supply chain resilience in the global financial crisis: An empirical study." Supply Chain Management: An International Journal, 16(4), pp. 246-259.

Kedia, B. L. and Lahiri, S. (2007). "International outsourcing of services: A partnership model." Journal of International Management, 13(1), pp. 22-37.

Kitano, H. (2004). "Biological robustness." Nature Reviews Genetics, 5(11), pp. 826-837.
Kwon, I. and Suh, T. (2006). "Factors affecting the level of trust and commitment in supply chain relationships." Journal of Supply Chain Management, 40(2), pp. 4-14.

Kwon, I. W. G. and Suh, T. (2005). "Trust, commitment and relationships in supply chain management: a path analysis." Supply Chain Management: An International Journal, 10(1), pp. 26-33.

Lahiri, S., \& Kedia, B. L. (2009). "The effects of internal resources and partnership quality on firm performance: An examination of Indian BPO providers." Journal of International Management, 15(2), 209-224.

Lahiri, S., Kedia, B. L., and Mukherjee, D. (2012). "The impact of management capability on the resourceperformance linkage: Examining Indian outsourcing providers." Journal of World Business, 47(1), pp. 145-155.

Lambert, D. M., Knemeyer, A. M. and Gardner, J. T. (2004). "Supply chain partnerships: model validation and implementation." Journal of business Logistics, 25(2), pp. 21-42

Lancastre, A. and Lages, L.F. (2006). "The relationship between buyer and $\mathrm{a} B \mathrm{~B}$ e-marketplace: cooperation determinants in an electronic market context." Industrial Marketing Management, 35(3), pp. 774-89.

Lynch, D. F., Keller, S. B., and Ozment, J. (2000). "The effects of logistics capabilities and strategy on firm performance." Journal of Business Logistics, 21(2), pp. 32- 47.

MacKinnon, D. P., Lockwood, C. M., Hoffman, J. M., West, S. G., \& Sheets, V. (2002). "A comparison of methods to test mediation and other intervening variable effects." Psychological methods, 7(1), 83.

Mentzer, J. T. and Williams, L. R. (2001). "The Role of Logistics Leverage in 
Marketing Strategy." Journal of Marketing Channels, 8(3), 29-48.

Mentzer, J. T., Min, S. and Bobbitt, L. M. (2004). "Toward a unified theory of logistics." International Journal of Physical Distribution \& Logistics Management, 34(8), pp. 606-627.

Morgan, R. M., and Hunt, S. D. (1991). "The commitment-trust theory of relationship marketing." The Journal of Marketing, 2(5), pp.20-38.

Moorman, C., Deshpande, R. and Zaltman, G. (1993). "Factors affecting trust in market research relationships." The Journal of Marketing, 28(2), pp. 81101.

Morash, E. A., Droge, C.L. M. and Vickery, S.K. (1996). "Strategic Logistics Capabilities for Competitive Advantage and Firm Success." Journal of Business Logistics, 17(1), pp. 1-22.

Mohr, J., and Spekman, R. (1994). "Characteristics of partnership success: partnership attributes, communication behavior, and conflict resolution techniques." Strategic Management Journal, 15(2), pp. 135152.

Naor, M., Linderman, K., and Schroeder, R. (2010). "The globalization of operations in eastern and western countries: Unpacking the relationship between national and organizational culture and its impact on manufacturing performance." Journal of Operations Management, 28(2), pp.194-205.

Natarajarathinam, M., Capar, I., and Narayanan, A. (2009). "Managing supply chains in times of crisis: A review of literature and insights." International Journal of Logistics Management, 19(7), pp. 535-573.

Nagel, R. and Dove, R. (1991),21st Century Manufacturing Enterprise Strategy An Industry Led Review, Vols 1 and 2, lacocca Institute, Lehigh University, Bethlehem, PA

Naudé, P., and Buttle, F. (2000). "Assessing relationship quality." Industrial Marketing Management, 29(4), pp. 351-361.

Peng, D. X., \& Lai, F. (2012). "Using partial least squares in operations management research: A practical guideline and summary of past research." Journal of Operations Management, 30(6), 467-480.

Podsakoff, P. M., MacKenzie, S. B., Lee, J. Y., and Podsakoff, N. P. (2003). "Common method biases in behavioral research: A critical review of the literature and recommended remedies." Journal of Applied Psychology, 88(1), pp. 879-903.

Ponomarov, S. Y., and Holcomb, M. C. (2009). "Under-standing the concept of supply chain resilience." International Journal of Logistics Management, 20(1), pp. 124-143.

Preacher, K. J., \& Hayes, A. F. (2008). "Asymptotic and resampling strategies for assessing and comparing indirect effects in multiple mediator models." Behavior research methods, 40(3), 879-891.

Pruitt, D. G. (1981). Negotiation Behavior. Academic Press, New York.

Rauyruen, P., and Miller, K. E. (2007). "Relationship quality as a predictor of B2B customer loyalty." Journal of Business Research, 60(1), pp. 21-31.

Rai, A., Patnayakuni, R., and Seth, N. (2006). "Firm performance impacts of digitally enabled supply chain integration capabilities." MIS Quarterly, 26(2), pp. 225-246

Rai, A., and Tang, X. (2010). "Leveraging IT capabilities and competitive process capabilities for the management of inter-organizational relationship portfolios." Information Systems Research, 21(3), pp. 516-542. 
Ruben, C. C., Paparoidamis, N. G., and Chung, C. (2015). The Impact of Service Quality, Relationship Satisfaction, Trust and Commitment on Loyalty: An Empirical Investigation in a Business-to-Business Services Context. In Revolution in Marketing: Market Driving Changes (pp. 91-91). Springer International Publishing.

Sandberg, E. and Abrahamsson, M. (2011). "Logistics capabilities for sustainable competitive advantage." International Journal of Logistics Research and Applications: A Leading Journal of Supply Chain Management, 14(1), pp. 61-75.

Scholten, K., Scott, P., and Fynes, B. (2014). "Mitigation processes-antecedents for building supply chain resilience." Supply Chain Management: An International Journal, 19(2), pp. 82-89.

Sirmon, D. G., Hitt, M. A., and Ireland, R. D. (2007), "Managing firm resources in dynamic environments to create value: Looking inside the black box", Academy of Management Review, Vol 32 No 1, pp. 273-292.

Sirmon, D. G., Gove, S., and Hitt, M. A. (2008)." Resource management in dyadic competitive rivalry: The effects of resource bundling and deployment." Academy of Management Journal, Vol 51(5), pp. 919-935.

Srinivasan, M., Mukherjee, D. and Gaur, A. S. (2011). "Buyer-supplier partnership quality and supply chain performance: Moderating role of risks, and environmental uncertainty." European Management Journal, 29(4), pp. 260271.

Stank, T.P., David, B.R. and Fugate, B.S. (2005). "A strategic framework for supply chain oriented logistics." Journal of Business Logistics, 26(2), pp. 27-45.

Stonebraker, P. W., Goldhar, J., and Nassos, G. (2009). "Weak links in the supply chain: Measuring fragility and sustainability." Journal of Manufacturing Technology Management, 20(3), pp. 161-177.

Su, Q., Song, Y. T., Li, Z., and Dang, J. X. (2008). "The impact of supply chain relationship quality on cooperative strategy." Journal of Purchasing and Supply Management, 14(4), pp. 263272.

Swafford, P.M., Ghosh, S. and Murthy, N. (2006). "The antecedents of supply chain agility of a firm: scale development and model testing." Journal of Operations Management, 24(2), pp. 170-88.

Swafford, P.M., Ghosh, S. and Murthy, N. (2008). "Achieving supply chain agility through IT integration and flexibility." International Journal of Production Economics, 116(2), pp. 288-297.

Tan, H., and Lim, A. (2009). "Trust in Coworkers and Trust in Organizations." The Journal of Psychology, 143(1), pp.45-66.

Teece, D. J., Pisano, G., and Shuen, A. (1997). "Dynamic capabilities and strategic management." Strategic Management Journal, 18(7), pp. 509533.

Tenenhaus, M., Vinzi, V. E., Chatelin, Y. M., \& Lauro, C. (2005). "PLS path modeling." Computational statistics \& data analysis, 48(1), 159-205.

Vinodh, S. (2010). "Improvement of agility and sustainability: a case study in an Indian rotary switches manufacturing organization." Journal of Cleaner Production, 18(10/11), pp. 1015-20.

Vlajic, J. V., van Lokven, S. W. M., Haijema, R., and Van der Vorst, J. G. (2012). "Using vulnerability performance indicators to attain food supply chain robustness." Production Planning \& Control, 24(9), pp.785-799.

Wathne, K. H., and Heide, J. B. (2004). "Relationship governance in a supply 
chain network." Journal of Marketing, 43(5), pp. 73-89.

Wagner, S. M., and Bode, C. (2008). "An empirical examination of supply chain performance along several dimensions of risk." Journal of Business Logistics, 29(1), pp. 307-325.

Wagner, S. M., and Neshat, N. (2011). "A comparison of supply chain vulnerability indices for different categories of firms." International Journal of Production Research, 50(11), pp. 2877-2891.

Wong, A., and Sohal, A. (2002). "An examination of the relationship between trust, commitment and relationship quality." International Journal of Retail \& Distribution Management, 30(1), pp. 34-50.

Wen, Y. (2012). "Impact of Collaborative Transportation Management on Logistics Capability and Competitive Advantage for the Carrier." Transportation Journal, 51(4), pp. 452-73.

Wernerfelt, B. (1984). "A resource-based view of the firm." Strategic Management Journal, 5(2), pp. 171180.

Wieland, A. and Wallenberg, C. M. (2013). "The influence of relational competencies on supply chain resilience: a relational view." International Journal of Physical Distribution \& Logistics Management, 43(4), pp. 300-320.

Williamson O, E. (1985), The economic institutions of capitalism: Firms, markets, relational contracting. New York.

Wu, L., Chuang, C. H. and Hsu, C. H. (2014). "Information sharing and collaborative behaviors in enabling supply chain performance: A social exchange perspective." International Journal of Production Economics, 148, pp. 122-132.
Wu, F., and Cavusgil, S. T. (2006) "Organizational learning, commitment, and joint value creation in interfirm relationships." Journal of Business Research, 59(1), pp. 81-89.

Zand, D.E. (1972). "Trust and Managerial problem solving". Administrative Science Quarterly, 17(3), pp. 229-239.

Zaheer, A., McEvily, B., and Perrone, V. (1998). "Does trust matter? Exploring the effects of interorganizational and interpersonal trust on performance." Organization Science, 9(2), pp. 141159.

Zhao, M., Dröge, C. and Stank, T. P. (2001). "The effects of logistics capabilities on firm performance: customer -focused versus information - focused capabilities." Journal of Business Logistics, 22(2), pp. 91-107.

Zhao, X., Lynch, J. G., \& Chen, Q. (2010). "Reconsidering Baron and Kenny: Myths and truths about mediation analysis." Journal of consumer research, 37(2), 197-206.

\section{About the Author}

Dr. Santanu Mandal is Assistant Professor at IBS Hyderabad, IFHE University in the Department of Operations \& IT. He was a visiting scholar at Spears School of Business under Oklahoma State University. His research interests typically include but not limited to: supply chain management, operations management, healthcare management and information systems. 